NBER WORKING PAPER SERIES

ASIAPHORIA MEETS REGRESSION TO THE MEAN

\author{
Lant Pritchett \\ Lawrence H. Summers \\ Working Paper 20573 \\ http://www.nber.org/papers/w20573 \\ NATIONAL BUREAU OF ECONOMIC RESEARCH \\ 1050 Massachusetts Avenue \\ Cambridge, MA 02138 \\ October 2014
}

We would like to thank David Yang for his able assistance and discussants Chang-Tai Hsieh and Robert Feenstra and participants at the 2013 Asian Economic Policy Conference for helpful comments and insights. The views expressed herein are those of the authors and do not necessarily reflect the views of the National Bureau of Economic Research.

NBER working papers are circulated for discussion and comment purposes. They have not been peerreviewed or been subject to the review by the NBER Board of Directors that accompanies official NBER publications.

(C) 2014 by Lant Pritchett and Lawrence H. Summers. All rights reserved. Short sections of text, not to exceed two paragraphs, may be quoted without explicit permission provided that full credit, including (C) notice, is given to the source. 
Asiaphoria Meets Regression to the Mean

Lant Pritchett and Lawrence H. Summers

NBER Working Paper No. 20573

October 2014

JEL No. E0,E6,F01,O4,O53

\begin{abstract}
Consensus forecasts for the global economy over the medium and long term predict the world's economic gravity will substantially shift towards Asia and especially towards the Asian Giants, China and India. While such forecasts may pan out, there are substantial reasons that China and India may grow much less rapidly than is currently anticipated. Most importantly, history teaches that abnormally rapid growth is rarely persistent, even though economic forecasts invariably extrapolate recent growth. Indeed, regression to the mean is the empirically most salient feature of economic growth. It is far more robust in the data than, say, the much-discussed middle-income trap. Furthermore, statistical analysis of growth reveals that in developing countries, episodes of rapid growth are frequently punctuated by discontinuous drop-offs in growth. Such discontinuities account for a large fraction of the variation in growth rates. We suggest that salient characteristics of China-high levels of state control and corruption along with high measures of authoritarian rule-make a discontinuous decline in growth even more likely than general experience would suggest. China's growth record in the past 35 years has been remarkable, and nothing in our analysis suggests that a sharp slowdown is inevitable. Still, our analysis suggests that forecasters and planners looking at China would do well to contemplate a much wider range of outcomes than are typically considered.
\end{abstract}

\title{
Lant Pritchett
}

Harvard Kennedy School

79 JFK St.

Cambridge, MA 02138

lant_pritchett@harvard.edu

Lawrence H. Summers

Harvard Kennedy School of Government

79 JFK Street

Cambridge, MA 02138

and NBER

lhs@ harvard.edu 


\section{Introduction ${ }^{1}$}

The rise of Asia is a story in at least four parts, with the fourth yet to be written. The first is the dramatic rise of Japan before and after World War II, ultimately to a prosperous and productive economy and global leader by the late 1980s. The second is the rise beginning in the 1960s of the East Asian Dragons - led by the four "Asian Tigers" of Korea, Taiwan, Singapore, and Hong Kong and followed by the three larger economies of Southeast Asia, Malaysia, Indonesia, and Thailand. The third is the rise of the Asian Giants with populations of over one billion. China and India each have more than twice the population of the other eight East Asian economies combined.

At least since the 1980s, economic growth accelerated in both China and India and then, surprisingly given usual historical patterns, accelerated again in both countries in the 1990s. That was followed by another acceleration in India in the mid-2000s (Kar, Pritchett, Raihan, and Sen 2013). The power of compound interest over long periods at high rates plus their sheer scale in population have led both economies to become global economic powerhouses. In purchasing power parity data (PPP) from the Penn World Tables (PWT) 8.0 (Feenstra, Inklaar and Timmer 2013), the three largest economies in the world in 2011 are the United States, China, and India. China's economy is now, again at PPP, roughly three times Japan's and four times Germany's. ${ }^{2}$

The fourth stage of this Asian story, the future, is unknown. Extrapolating a decade or two into the future - based on recent growth rate differentials between China and India, the modest

\footnotetext{
${ }^{1}$ Author's note: We would like to thank David Yang for his able assistance and discussants Chang-Tai Hsieh and Robert Feenstra and participants at the 2013 Asian Economic Policy Conference for helpful comments and insights.

${ }^{2}$ This, for now, begs the question of whether PPP, which is appropriate for comparisons of living standards, is the right metric for global influence, as international trade obviously happens at actual, not PPP, exchange rates.
} 
post-crisis growth of the United States, and the even more modest recent growth in Europeproduces an Asiaphoria, the view that the global economy will increasingly be shaped and lifted by the trajectory of the Giants. Combined with continued growth in the other large Asian economies that still have low to middle incomes - for example, Vietnam, Indonesia, and Thailand - the vision of the global economic center of gravity shifting even more decisively to Asia becomes destiny.

Asiaphoria has become almost conventional wisdom. Looking to 2060: Long-Term Global Growth Prospects (OECD 2012) forecasts per capita growth from 2011 to 2030 for China of 6.6 percent and for India, 6.7 percent. In China 2030 (2012), the World Bank and the Development Research Center of the State Council of China project output per worker growth rates of 8.3 percent from 2011 to 2015, 7.1 percent from 2016 to 2020, and 6.2 percent from 2021 to 2025 . In its official National Intelligence Estimates projected out to 2030, the U.S. intelligence community presents scenarios implying China's share of the world economy will grow from 6.4 percent in 2010 to between 17 and 23 percent in 2030; for India the estimates for the same periods are growth building from 1.8 percent of the world economy to between 6.5 and 7.9 percent. And these are cautious when contrasted with Fogel's (2010) prediction that China's GDP will reach US\$123 trillion by 2040 .

Our principle contribution is a rigorous quantitative demonstration that with respect to economic growth - just as investment firms warn is true about returns - past performance is no guarantee of future performance. Regression to the mean is perhaps the single most robust and empirical relevant fact about cross-national growth rates. The lack of persistence in country growth rates over medium- to long-run horizons implies current growth has very little predictive power for future growth. Hence, while it might be the case that China will continue for another 
two decades at 9 (or even 7 or 6) percent per capita growth, given the regression to the mean present in the cross-national data, where historically the distribution of growth has been an average of 2 percent with a standard deviation of 2 percent, this would be an extraordinary tail event. Similarly, while it might be the case that Indian growth continues at 6 percent, this would require India's extended growth, already rare, to persist even longer and become rarer still.

Many of the great economic forecasting errors of the past half century came from excessive extrapolation of performance in the recent past and treating a country's growth rate as a permanent characteristic rather than a transient condition. Paul Samuelson's textbook predicted in 1961 that there was a substantial chance that the USSR would overtake the United States economically by the 1980 s. There was a widespread view right up until the end of the 1980 s that Japan would continue to grow and outcompete the world. Or in the opposite direction, consider the pervasive pessimism of even a decade ago regarding Africa. Since then, African countries emerged as a majority of the world's most rapidly growing nations.

In addition to demonstrating that past growth performance is of very little value for forecasting the central tendency of future growth, we also show that in developing countries the growth process is marked by sharp discontinuities, with very large accelerations or decelerations of growth being quite common. This implies that the explicit (or implicit) confidence intervals in typical forecasts or the range of growth that scenarios consider might dramatically underestimate the actual range of outcomes. The recent crisis has again alerted us to the fact that risks of downside scenarios are often vastly underestimated, ${ }^{3}$ just as the fragility in systems is underestimated. Moreover it appears that particular aspects of China's situation —a high degree

\footnotetext{
${ }^{3}$ The recent crisis has again reminded researchers of the distinction between risk and Knightian uncertainty (e.g., Greenspan 2013). Silver (2012) argues the models being used by the risk-rating agencies underestimated the default risk of some bonds not by percentage points or even a single order of magnitude, but by a factor of 200 .
} 
of government discretion vis-à-vis businesses and an authoritarian regime — add to the likelihood of a growth slowdown.

Our paper is organized as follows. Section 2 presents the basic evidence on regression to the mean in country growth rates and shows how taking account of this evidence leads to forecasts for Chinese and Indian growth that are much more pessimistic than consensus views. Section 3 demonstrates the robustness of the conclusion to a variety of specifications. Section 4 draws on recent work by Kar, Pritchett, Raihan, and Sen (2013) that extends work on "stop-start" growth (e.g., Rodrik 1999 and Jones and Olken 2008) and shows the extent to which the growth process is marked by changes in "growth regimes" with large accelerations and decelerations. This is a very different view than the standard trend-cycle model used in industrial country macroeconomics, but it appears to be much more descriptive of developing countries where "the cycle is the trend" (Aguiar and Gopinath 2007). We show that rapidly growing countries are substantially more likely to suffer a downward discontinuity in growth than an upward movement. Our analysis also suggests that growth declines are more likely to be sudden and large than gradual and small. Section 4 also demonstrates that, in considering China's prospects for continued rapid growth, the much-discussed middle income trap (if, properly measured, it even exists) is less a fundamental empirical issue than a simple regression to the mean. Finally, Section 5 considers two qualitative aspects of the Chinese situation - China's high degree of dependence on discretionary policies towards business and its authoritarian character. We show that both make sharp declines in growth more likely. A final section concludes and discusses some implications of the results.

2. The $\$ 42$ Trillion Question: Will Rapid Growth in China and India Persist? 


\subsection{Regression to the Mean: The Single Most Robust Fact about Growth}

The 1990s saw an explosion of "growth regressions" which placed the growth of gross domestic product per capita (GDPPC) over some period on the left-hand side and everything but the kitchen sink on the right (Wacziarg 2002 and Rodriguez and Shelton 2013). ${ }^{4}$ We are not going to characterize what was "learned," as the methodological sensitivity of growth regression findings about particular variables was an issue raised early (Levine and Renelt 1992) and often: Nearly every assertion about correlates (or causes) of growth emerging in any study has been challenged as not robust in a later study.

However, one fact about growth that emerged early_including a paper of ours with Bill Easterly and Michael Kremer (Easterly et al. 1993) — has stood the test of time and new data. There is strong regression to the mean in the growth process, hence very little persistence in country growth rate differences over time, and consequently current growth has a low predictive power for future growth. Although one might have thought that most of the long horizon growth differences were due to the existence of slow and fast growing countries (e.g., Argentina grows slow and Japan grows fast) — the opposite is true and nearly all growth variation is due to differences within countries over time.

Table 1 presents four measures of persistence: the correlation, the rank correlation (which reduces the influence of outliers), the regression coefficient of current growth on lagged growth, and the R-squared of the regression (which is of course the square of the correlation coefficient). We use the PWT8.0 (Feenstra, Inklaar, and Timmer 2013) data on local currency real GDP from national accounts (since we are not yet comparing levels) and population to compute real

\footnotetext{
${ }^{4}$ Barro's 1991 paper alone has over 10,000 citations in Google Scholar and Xavier Sala-i-Martin (1997) alone takes personal credit for four million growth regressions. One suspects the exclusion of the kitchen sink was more a lack of easily downloadable cross-national kitchen sink data than any reluctance to use such data in a growth regression.
} 
GDPPC. We compute least-squares growth rates of natural log GDPPC for 10 and 20 year periods for all countries with sufficient data. ${ }^{5}$ The results show that the low persistence of growth has been a consistent and robust characteristic across all decades - if anything there is less persistence in the recent decadal growth rates (1990-2000 to 2000-10) than in previous decades. ${ }^{6}$ Not surprisingly, the persistence declines over longer periods so that using current growth rates to predict two decades ahead has even less predictive power than predicting one decade ahead.

\footnotetext{
${ }^{5}$ We calculate a growth rate if there is more than 7 years of data for the 10-year growth rates and 14 years of data for the 20 year period (e.g., we include a 10-year growth rate for the 1950s for countries with data starting in 1953). We exclude countries with less than 25 years of data - which removes all of the successor nation-states of the former Soviet Union from calculations in this paper. We also exclude Equatorial Guinea because it has a small population and is frequently a massive outlier.

${ }^{6}$ The basic findings in Easterly et al. (1993) Table 1 were a correlation of 0.313 for 100 countries from 1970 s to $1980 \mathrm{~s}$ (compare 0.337 in the current results) and 0.212 from 1960s to 1970 s (compare 0.339 for 108 countries in the current results).
} 


\begin{tabular}{|c|c|c|c|c|c|c|}
\hline Period 1 & Period 2 & Correlation & $\begin{array}{l}\text { Rank } \\
\text { Correlation }\end{array}$ & $\begin{array}{l}\text { Regression } \\
\text { Coefficient }\end{array}$ & R-squared & $\mathrm{N}$ \\
\hline \multicolumn{7}{|c|}{ Adjacent decades } \\
\hline $1950-60$ & $1960-70$ & 0.363 & 0.381 & 0.378 & 0.132 & 66 \\
\hline $1960-70$ & $1970-80$ & 0.339 & 0.342 & 0.382 & 0.115 & 108 \\
\hline $1970-80$ & $1980-90$ & 0.337 & 0.321 & 0.323 & 0.114 & 142 \\
\hline \begin{tabular}{|l|}
$1980-90$ \\
\end{tabular} & $1990-00$ & 0.361 & 0.413 & 0.288 & 0.130 & 142 \\
\hline \begin{tabular}{|l|}
$1990-00$ \\
\end{tabular} & $2000-10$ & 0.237 & 0.289 & 0.205 & 0.056 & 142 \\
\hline \multicolumn{7}{|c|}{ One decade apart } \\
\hline $1950-60$ & $1970-80$ & 0.079 & 0.192 & 0.095 & 0.006 & 66 \\
\hline $1960-70$ & $1980-90$ & 0.279 & 0.312 & 0.306 & 0.078 & 108 \\
\hline \begin{tabular}{|l|}
$1970-80$ \\
\end{tabular} & $1990-00$ & 0.214 & 0.214 & 0.163 & 0.046 & 142 \\
\hline $1980-90$ & $2000-10$ & 0.206 & 0.137 & 0.143 & 0.043 & 142 \\
\hline \multicolumn{7}{|c|}{ Two decades apart } \\
\hline $1960-70$ & $1990-2000$ & 0.152 & 0.177 & 0.152 & 0.023 & 108 \\
\hline $1970-80$ & $2000-2010$ & -0.022 & 0.005 & -0.015 & 0.001 & 142 \\
\hline
\end{tabular}

The results in Table 2 using growth rates over 20 year periods - which smooth even more over "cyclical" fluctuations — are similar in showing strong regression to the mean, low persistence, and low predictive power of current growth for future growth. 


\begin{tabular}{|c|c|c|c|c|c|c|}
\hline \multicolumn{7}{|c|}{ predicting future growth } \\
\hline Period 1 & Period 2 & Correlation & $\begin{array}{l}\text { Rank } \\
\text { correlation }\end{array}$ & $\begin{array}{l}\text { Regression } \\
\text { Coefficient }\end{array}$ & R-squared & $\mathrm{N}$ \\
\hline \multicolumn{7}{|c|}{ Adjacent two decade periods } \\
\hline $1950-70$ & $1970-1990$ & 0.258 & 0.318 & 0.343 & 0.067 & 70 \\
\hline $1960-80$ & $1980-2000$ & 0.459 & 0.454 & 0.494 & 0.211 & 108 \\
\hline $1970-90$ & $1990-2010$ & 0.327 & 0.325 & 0.215 & 0.107 & 142 \\
\hline \multicolumn{7}{|c|}{ Gap of two decades } \\
\hline $1950-70$ & $1990-2010$ & 0.047 & 0.015 & 0.047 & 0.002 & 70 \\
\hline
\end{tabular}

For the question at hand-Will the rapid growth rates of the Asian Giants continue into coming decades as an engine of global growth? - the most relevant summary statistics are the regressions.

First, knowing the current growth rate only modestly improves the prediction of future growth rates over just guessing it will be the (future realized) world average. The R-squared of decade-ahead predictions of decade growth varies from 0.056 (for the most recent decade) to 0.13. Past growth is just not that informative about future growth and its predictive ability is generally even lower over longer horizons.

Second, if all we knew was a country's current growth rate then what would be the best prediction of the future? The extremes are extrapolation, a coefficient of 1 , and exclusion, a 
coefficient of zero. Our estimates imply that the coefficients are around 0.3 for decade-ahead predictions and lower if current decades are used to predict further ahead, 0.2 or less.

Essentially what is being asserted here is the equivalent of the Time magazine cover curse. It has been observed that public figures who appear on the cover of Time often suffer a career reversal soon afterwards. This is just what one would expect with mean reversion and extrapolative expectations. Those who perform best in period $t$ will on average perform much worse than expected in period $t+1$.

At a deeper level, the finding of high mean reversion in growth rates has profound implications for the study of economic growth. If it were the case as many models suggest that some relatively constant feature of countries - their climate, their culture, their geography, the quality of their institutions, or their openness to the world as examples - influenced growth, importantly one would expect since these variables persist that growth rates would persist. However, in the data, growth rates do not persist. This empirical finding suggests that these constant features affect the level more than the medium to long period growth of incomes. It also suggests that even the most favorable conditions will ultimately have diminishing impacts on growth, unless a country can continually improve its policy environment or governance.

\subsection{Forecasting the future level of GDP in the Giants}

What are the mechanical implications for the predicted growth of dollar GDP of China and India of "extrapolation of current growth" versus regression to the mean? By "mechanical" we just mean, what we would expect to happen if we did not know anything about China or India and just treated them as if they would follow the statistical regularities that apply to other countries? 
We create predictions of growth rates in future decades using regressions that predict countries' growth rates based on their past decades growth (and their initial levels of income in PPP to allow for convergence). Predictions then just plug China's and India's current growth rates and levels of income into that equation and roll these predictions forward for two decades. The basic idea (on which we experiment with many variants) is to estimate equation 1:

$$
\text { (1) } g_{00-10}^{i}=\alpha+\beta * g_{90-00}^{i}+\gamma * \ln \left(y_{00}^{i}\right)+\varepsilon^{i}
$$

and then predict growth ahead for two decades using the estimated coefficients and the actual values for China and India for the first decade and the predicted growth (and consequent level) for the first decade in predicting the second.

$$
\begin{gathered}
g p_{13-23}^{\text {China }}=\hat{\alpha}+\hat{\beta} * g_{00-10}^{\text {China }}+\hat{\gamma} * \ln \left(y_{2010}^{\text {China }}\right) \\
g p_{23-33}^{\text {China }}=\hat{\alpha}+\hat{\beta} * g p_{13-23}^{\text {China }}+\hat{\gamma} * \ln \left(y p_{2023}^{\text {China }}\right)
\end{gathered}
$$

Table 3 shows the results of a variety of simple "regression to the mean" regressions, with and without convergence terms, with and without two decades of lags, and for 10 versus 20 year time periods. Not surprisingly given the robustness of weak persistence as a feature of growth rates demonstrated above, all regressions produce coefficients on lagged growth between 0.20 and 0.32 . 


\begin{tabular}{|c|c|c|c|c|c|c|c|}
\hline \multicolumn{8}{|c|}{ lagged level of income } \\
\hline $\begin{array}{l}\text { Dependent } \\
\text { variable }\end{array}$ & & Constant & $\begin{array}{l}\text { Lagged } \\
\text { growth }\end{array}$ & $\begin{array}{l}\text { Second } \\
\text { lag of } \\
\text { growth }\end{array}$ & $\begin{array}{l}\text { Initial } \\
\text { Level of } \\
\text { GDPPC }\end{array}$ & $\begin{array}{l}\text { R- } \\
\text { Squared }\end{array}$ & $\mathrm{N}$ \\
\hline \multirow{2}{*}{$\begin{array}{l}\text { Growth } \\
2000-2010\end{array}$} & Coefficient & 0.023 & 0.205 & & & \multirow[t]{2}{*}{0.056} & 142 \\
\hline & t-stat & 10.758 & 2.887 & & & & \\
\hline \multirow{2}{*}{$\begin{array}{l}\text { Growth } \\
2000-2010\end{array}$} & Coefficient & 0.068 & 0.329 & & -0.006 & \multirow[t]{2}{*}{0.177} & 142 \\
\hline & t-stat & 6.632 & 4.572 & & -4.519 & & \\
\hline \multirow{2}{*}{$\begin{array}{l}\text { Growth } \\
2000-2010\end{array}$} & Coefficient & 0.074 & 0.274 & 0.161 & -0.006 & \multirow[t]{2}{*}{0.222} & 142 \\
\hline & t-stat & 7.227 & 3.749 & 2.812 & -5.135 & & \\
\hline \multirow{2}{*}{$\begin{array}{l}\text { Growth } \\
1990-2000\end{array}$} & Coefficient & -0.009 & 0.240 & 0.045 & 0.003 & \multirow[t]{2}{*}{0.157} & 142 \\
\hline & t-stat & -0.665 & 3.561 & 0.683 & 1.679 & & \\
\hline \multirow{2}{*}{$\begin{array}{l}\text { Growth } \\
1990-2010\end{array}$} & Coefficient & 0.031 & 0.241 & & -0.001 & \multirow[t]{2}{*}{0.117} & 142 \\
\hline & t-stat & 3.164 & 4.272 & & -1.243 & & \\
\hline & & & & & & & \\
\hline
\end{tabular}

Because our primary interest is the impact on the global economy, we predict total GDP in dollars (not PPP adjusted) for China and India over the next two decades ${ }^{7}$. To predict population we use the United Nations Medium Fertility projections, which show China's

\footnotetext{
${ }^{7}$ On one level this choice of official versus PPP is inconsequential for our basic point as the proportionate changes would be the same whatever base we use, since we are not assuming any changes in exchange rates. Obviously by using the base of official exchange rates we make the Chinese and Indian economies look relatively smaller to the U.S. (or OECD) economies and hence PPP calculations would make the relative sizes even more dramatic. However, to do PPP we would have to something about the relationship between level of income and PPP prices over time, which complicates our calculations in a not useful way.
} 
population growth near zero while India's continues to grow about 1 percent per year over the next decade and then slows.

We start the scenarios using the International Monetary Fund (IMF) World Economic Outlook 2013 U.S. dollar GDP (which is somewhat a forecast, as it, for instance, already includes the depreciation of the rupee in 2013). We compute total dollar GDP for 2023 and 2033 by simply using an assumed growth rate of GDP per capita and then multiplying by population.

The results are at the same time both obvious and striking. If one assumes a continuation of current growth rates, the 20 year gain in GDP from 2013 to 2033 in China would be $\$ 51.1$ trillion (from $\$ 8.9$ to $\$ 60$ trillion), which would be a gain in GDP more than three times as large as the current U.S. economy. The continuation of current growth rates would make China far and away the world's dominant economy. The gain in India would be smaller (as it begins from a lower base and at a lower growth rate, of 6 percent) but still rises to a substantial $\$ 6.8$ trillion for a gain of \$5.1 trillion (the current size of France and Italy combined). Even if one assumes growth slows in China to 7 percent its total GDP grows to $\$ 36$ trillion-more than twice the current U.S. level.

However, it is also obvious that regression to the mean of the ordinary type would reduce these gains massively. Under any of the empirical estimates for "regression to the mean," the level of China's GDP in 2033 would fall to around \$20 trillion-which still implies a 20 year increase in GDP of around $\$ 11$ trillion. Similarly, the gains in India fall from $\$ 5$ trillion to between $\$ 2.4$ and $\$ 3.3$ trillion. Forecasts based on past growth and levels predict growth that is closer to the naive expectation that China and India grow like average countries than to extrapolations of their past growth. 
There is some consensus that China will not maintain 9 to 10 percent growth rates, but even the view that China's growth will slow to something like 7 percent assumes substantial persistence. The predicted growth over the next two decades using regressions is 3.9 percent (with a coefficient on past growth of 0.24 ), and the regression standard error of estimation is 1.6 percent, so a continuation of even 7 percent is two standard deviations in the tail, and a continuation of a growth rate of 9 percent is three standard deviations.

\begin{tabular}{|c|c|c|c|c|c|}
\hline \multirow[t]{2}{*}{ Scenarios } & & \multicolumn{2}{|c|}{$\begin{array}{l}\text { China } \\
\text { (GDP in } 2013=\$ 8,939 \\
\text { bn) }\end{array}$} & \multicolumn{2}{|c|}{$\begin{array}{c}\text { India } \\
(\text { GDP in } 2013=\$ 1,758 \\
\text { bn) }\end{array}$} \\
\hline & & 2023 & 2033 & 2023 & 2033 \\
\hline \multirow[t]{2}{*}{ Continuation of 2000-2010 growth } & $\begin{array}{l}\text { Growth } \\
\text { GDPPC }\end{array}$ & $9.74 \%$ & $9.74 \%$ & $6.01 \%$ & $6.01 \%$ \\
\hline & $\begin{array}{l}\text { GDP } \\
\text { (billions) }\end{array}$ & $\$ 23,592$ & $\$ 60,034$ & $\$ 3,508$ & $\$ 6,804$ \\
\hline \multirow[t]{2}{*}{ Growth at 7 percent } & $\begin{array}{l}\text { Growth } \\
\text { GDPPC }\end{array}$ & $7.00 \%$ & $7.00 \%$ & $7.00 \%$ & $7.00 \%$ \\
\hline & $\begin{array}{l}\text { GDP } \\
\text { (billions) }\end{array}$ & $\$ 18,329$ & $\$ 36,238$ & $\$ 3,849$ & $\$ 8,188$ \\
\hline \multirow[t]{2}{*}{$\begin{array}{l}\text { Falls to } 2 \text { percent (full regression to } \\
\text { mean) }\end{array}$} & $\begin{array}{l}\text { Growth } \\
\text { GDPPC }\end{array}$ & $2.00 \%$ & $2.00 \%$ & $2.00 \%$ & $2.00 \%$ \\
\hline & $\begin{array}{l}\text { GDP } \\
\text { (billions) }\end{array}$ & $\$ 11,358$ & $\$ 13,915$ & $\$ 2,385$ & $\$ 3,144$ \\
\hline \multirow[t]{2}{*}{$\begin{array}{l}\text { Predicted growth, } 10 \text { years, one lag, } \\
\text { convergence term }\end{array}$} & $\begin{array}{l}\text { Growth } \\
\text { GDPPC }\end{array}$ & $5.01 \%$ & $3.28 \%$ & $4.24 \%$ & $3.92 \%$ \\
\hline & $\begin{array}{l}\text { GDP } \\
\text { (billions) }\end{array}$ & $\$ 15,198$ & $\$ 21,100$ & $\$ 2,963$ & $\$ 4,708$ \\
\hline \multirow[t]{2}{*}{$\begin{array}{l}\text { Predicted growth, } 20 \text { years, } \\
\text { convergence term }\end{array}$} & $\begin{array}{l}\text { Growth } \\
\text { GDPPC }\end{array}$ & & $3.89 \%$ & & $3.00 \%$ \\
\hline & $\begin{array}{l}\text { GDP } \\
\text { (billions) }\end{array}$ & & $\$ 20,077$ & & $\$ 3,820$ \\
\hline
\end{tabular}

Table 5 shows that whether or not China and India will maintain their current growth or be subject to regression to the global mean growth rate is a $\$ 42$ trillion dollar question. The 
difference between the "continuation" scenario in 2033, in which the GDP of China plus India gains $\$ 56$ trillion, and the average of the "regression to the mean" scenarios (which are all quite similar, with total China plus India 2033 GDP between $\$ 12$ and $\$ 15.5$ trillion) is $\$ 42$ trillion dollars. The 7 percent scenario shows a gain of $\$ 33$ trillion versus $\$ 13$ trillion of the average of the regression to the mean scenarios.

\begin{tabular}{|c|c|c|c|}
\hline \multirow[t]{2}{*}{ Scenarios } & \multicolumn{3}{|c|}{ Gain in 2033 over 2013} \\
\hline & China & India & Total \\
\hline Continuation of current rates (Zero regression to mean) & $\$ 51,095$ & $\$ 5,046$ & $\$ 56,140$ \\
\hline Growth at 7 percent & $\$ 27,299$ & $\$ 6,429$ & $\$ 33,728$ \\
\hline Regression to 2 percent per year & $\$ 4,976$ & $\$ 1,386$ & $\$ 6,362$ \\
\hline Predicted regression to the mean 10 years, no convergence & $\$ 10,382$ & $\$ 2,591$ & $\$ 12,973$ \\
\hline Predicted regression to the mean, 10 years, with convergence & $\$ 12,160$ & $\$ 3,304$ & $\$ 15,464$ \\
\hline Predicted regression to the mean, 20 years, with convergence & $\$ 11,137$ & $\$ 2,416$ & $\$ 13,553$ \\
\hline $\begin{array}{l}\text { Average of three predicted "regression to mean" } \\
\text { scenarios }\end{array}$ & $\$ 11,227$ & $\$ 2,770$ & $\$ 13,997$ \\
\hline $\begin{array}{l}\text { Difference in gains to dollar GDP of China and India } \\
\text { between the "continuation" and "regression to mean" } \\
\text { scenarios }\end{array}$ & $\$ 39,868$ & $\$ 2,275$ & $\$ 42,144$ \\
\hline
\end{tabular}


This obviously affects the world growth rate substantially - even in the absence of any feedback effects on the rest of the world's economies. Table 6 shows the evolution of the world total GDP assuming the rest of the world grows steadily at 2 percent, reaching $\$ 93$ trillion in 2033. If China and India continued at their current rate, they would reach over $\$ 66$ trillion and hence just mechanically the annual growth rate of world GDP is 3.5 percent and then 4.45 percent in the next two decades (accelerating just because India and China mechanically have a larger share of the total). Conversely, with regression to the mean scenarios for China and India, the global growth rate is 2.48 percent and 2.27 percent. 


\begin{tabular}{l} 
Table 6: Mechanically, if the world grows at 2 percent and China and India continue they are a \\
larger and larger share of global GDP and growth of global GDP is higher. \\
Dollar amounts are in billions of dollars. \\
\hline Growth
\end{tabular}

Of course this mechanical calculation underestimates the role of China and India as growth engines by assuming that other country growth rates are not raised by faster growth in the giants. To the extent there are positive linkages, then this mechanical calculation underestimates (perhaps substantially) the impact on global growth of regression to the mean.

We are trying to reverse the default assumptions often made in forecasting GDP, which is that, in the absence of any reason to think otherwise, the current growth rate persists. In this view what has to be justified with argumentation is why the growth rate would decelerate. 
However, this mode of forecasting or projection or even formulation of scenarios is counterfactual to the single most robust fact about growth rates, which is strong reversion to the mean. Our argument is that the default prediction/projection/forecast should be that a country's growth rate will be subject to regression to the mean. What has to be justified with argumentation is why the growth rate would persist at rates higher (or lower) than the world mean growth rate.

For instance, in addressing the current question of whether Asia - and necessarily China and India as part of that - will be an engine of global growth over the future (not the short run of one to three years but the longer run of five to twenty years) our guess is that growth will slow, substantially, in those countries. Why will growth slow? Mainly, because that is what rapid growth does. Our confidence in the prediction that growth will slow is much larger than our confidence in being able to specify why or how or when exactly it will slow.

But this is like all other regression to the mean phenomena. If a hitter has a hot streak with a batting average up 50 points over the past 20 at bats, then we would forecast a return to the average batting average over the next 20 at bats (perhaps not exactly to the mean, but substantial regression). If pressed to say why the batting average would be lower one could speculate about why it currently is so high and predict those factors will diminish or predict future events will causally explain the lowering, but mainly, that is just what happens.

One might, at this stage, suspect us of attacking a straw man on two levels. First, no one really ignores regression to the mean in making forecasts. Second, the bullish views of growth in China and India have already softened considerably. 
predictability of growth than the historical data over similar periods. The regression of actual growth 2004-08 on actual growth 1993-2002 gives a coefficient of 0.255 (standard error of 0.128 ) and R-squared of 0.04 (similar to the results above, just adjusted to comparable periods of the forecast for comparison). The forecasts $2014-18$ on growth $2003-12$ has a slope of 0.481 (standard error 0.072) and R-squared of 0.263.

Figure 1: The IMF WEO forecasts show substantially more persistence in growth rates than present in the historical data

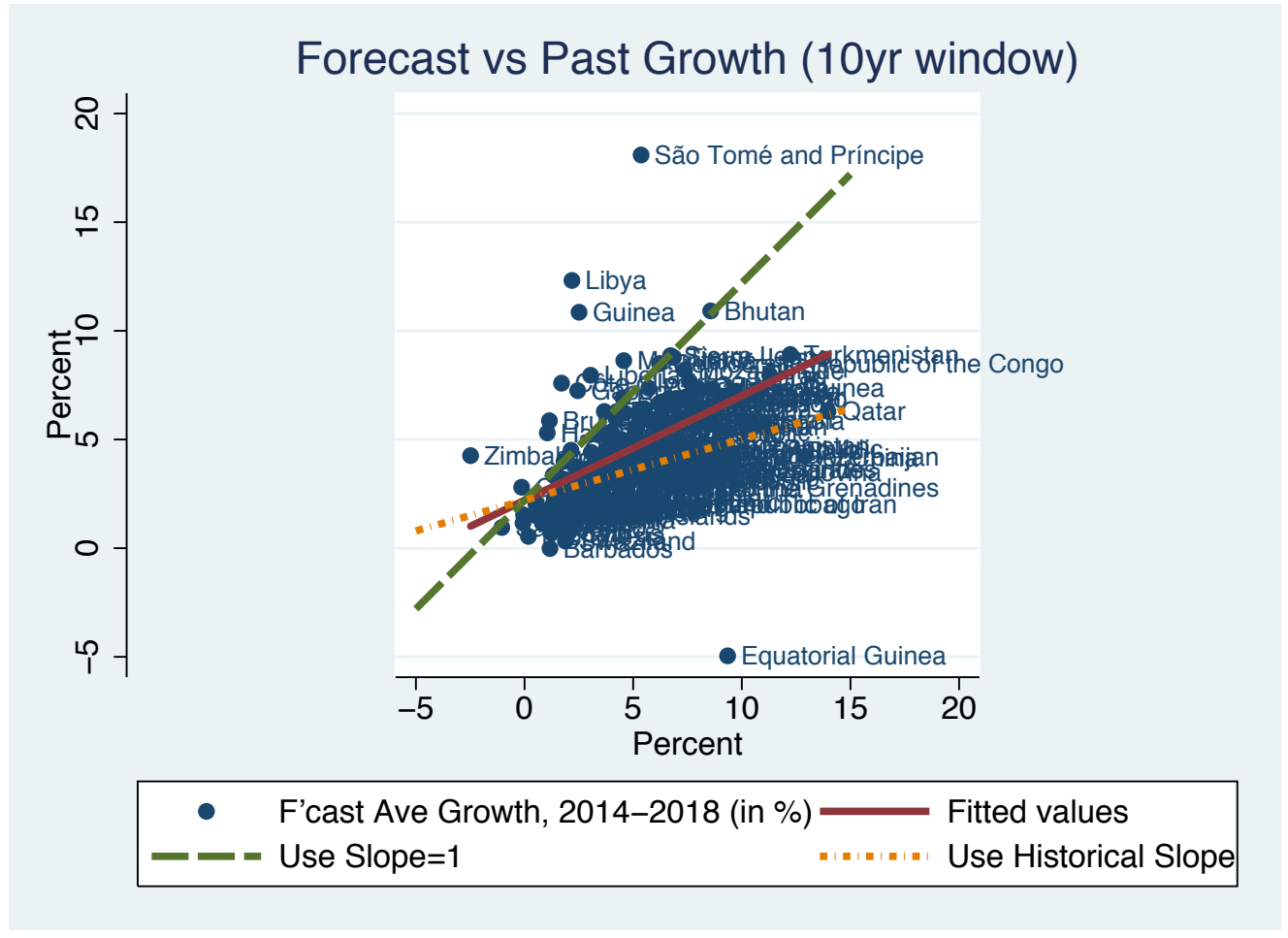

Source: Author's calculations using data from

http://www.imf.org/external/pubs/ft/weo/2013/02/weodata/ on October 302013.

One argument against the predictability of long-run growth is that it has in fact been possible to predict the per capita level of GDP far ahead. Suppose all you knew was that 
Denmark’s GDPPC measured in 1990 Geary-Khanis dollars was in 1910 GK\$3,891 and that its per capita annual rate of growth during the pre-World War I period of 1890-1916 was 1.90 percent and someone asked you to forecast GDPPC in Denmark almost 100 years ahead to 2010 using only pre-World War I information. While this might seem pointless, you could venture a guess that it was the simple extrapolation of exponential growth at GK\$23,212. ${ }^{8}$ Turns out, you would be right, exactly right. Actual GDPPC was GK\$23,513. The 94-year-ahead forecast of GDPPC was off by about $\$ 300$ - less than 1 percent. The long-run stability of growth in OECD countries is well-known ${ }^{9}$ to all economists, so well-known that it may cause misleading habits of thought. The leading countries have very stable growth rates (averaged over long periods) for a very long time. ${ }^{10}$ However, the apparently reliable prediction of the future is an artifact of growing near the mean growth rate so that extrapolations into the future and regression to the mean give similar answers. But in extrapolating growth rates, regression to the mean almost always wins.

\footnotetext{
${ }^{8} \mathrm{GK} \$ 23,212=\exp (\ln (3891)+(.0190 *(2010-1916))$.

${ }^{9}$ A figure showing the long-run stability of growth for the United States has been the cover of Charles Jones's textbook on economic growth.

${ }^{10}$ Of course, as also known at least since DeLong's critique of Baumol's assertions of convergence, the argument is somewhat circular that what it means to be a leading country is that it maintained a high growth rate. Argentina's GDPPC in 1890 was about the same as Austria, France, or Germany and much higher than Italy, Norway, Sweden, or Spain.
} 
3. Robustness of predicting future growth: years, levels, previous growth, country size

The first section has the virtue of simplicity: We compare forecasts with extrapolation to historically observed degrees of regression to the mean in a way that the simple framing of full persistence (extrapolation) is a coefficient of 1 and no persistence is a coefficient of zero. However, we want to reassure readers that the simple results are robust. In this section we address three issues: (a) whether growth predictability either increases with the use of longer past lags in growth or whether predictability has become better over time; (b) whether growth is more predictable in large than in small countries; and (c) whether regression to the mean is asymmetric such that growth booms are more likely to be sustained than growth busts.

\subsection{Variation in growth predictability over lags, leads, and time}

We generalize equation 1 to allow the window of past data $\left(N_{b}\right)$ and the length of the forecast $\left(N_{f}\right)$ to vary. ${ }^{11}$ This tests whether the low persistence is an artifact of some particular phase of global growth dynamics or a truly robust feature of the data.

$$
g_{t, t+N_{f}}^{i}=\alpha_{t}+\beta_{t} * g_{t, t-N_{b}}^{i}+\gamma_{t} * \ln \left(y_{t}^{i}\right)
$$

\footnotetext{
${ }^{11}$ One additional difference in this section is that we eliminate from all (a) one small country (Equatorial Guinea) that has unusual growth dynamics driven by oil, (b) five countries whose growth dynamics are driven by conflict (Liberia, Sierra Leone, Iraq, Democratic Republic of Congo, and Kuwait), and (c) all countries with population less than 600,000 . We think a reasonable case can be made that the parameters used in predicting growth in the giants of China and India should not be overly influenced by the growth dynamics of small or atypical outliers.
} 
The results of estimating this equation across all available countries (constrained so that the country sample is the same for all lags of $N_{b}$ ) are shown in Figure 2. Averaged over all years and across lags of 10,15 , and 20 years, the regression coefficient for predicting growth 10 years ahead is 0.333 . Hence the value of 0.329 for the 10 -year-ahead prediction with convergence term in Table 3 is neither atypically high nor low. The predictive power of this simple regression is low, averaging 0.141 and is consistently less than 0.25 so that knowing the present is not that informative about the future.

There is some time variation as growth became less predictable based on previous growth in the first half of the 1990s with some recovery in predictability in the late 1990s/early 2000s. Longer lags (perhaps capturing more permanent features of a country's growth) having more predictive power than 10-year lags in the 1980s but with the opposite result more recently. As detailed in the opening section, regression to the mean or lack of persistence is a robust finding over time and, while it varies, there has been no secular trend to greater persistence. Using the same lags of 10, 15, and 20 years to forecast 20 years ahead (which constrains the $t$ to be between 1980 and 1991 to have sufficient data) produces almost exactly the same average persistence coefficient of 0.33 . 
One feature of these regressions that does vary over time is the coefficient on the initial level of income. As is well-known, conditional convergence is a feature of cross-national growth rates - at least if you use the "right" conditioning variables (Barro 1991). But there is also (until recently) absolute divergence (in both levels and natural logs) as the cross-national variance increased over time (Pritchett 1997). Since by design these regressions are conditional only on past growth and initial level of income, the coefficient on lagged income is more like an unconditional than conditional convergence coefficient. Hence during most of this time period the coefficient on lagged income was actually small and positive (divergence). As is also wellknown, the financial crisis and the slowdown in the OECD countries led to more rapid growth in the developing countries. Hence towards the end of the period the lagged level of income actually predicted substantially faster growth in the poorer countries. For 2001, the latest year in which we could run 10-year-ahead regressions, this effect added 1.5 percent to the predicted annual growth of China and 2.0 to India. So, to a very large extent the regression to the mean effects that predict slower growth are offset in the most recent regressions by a historically atypically large unconditional (on policy variables) convergence term. 
Figure 2: Regressions predicting future (10 year ahead) on past (various lags) growth (and lagged level) show some, but consistently low predictability
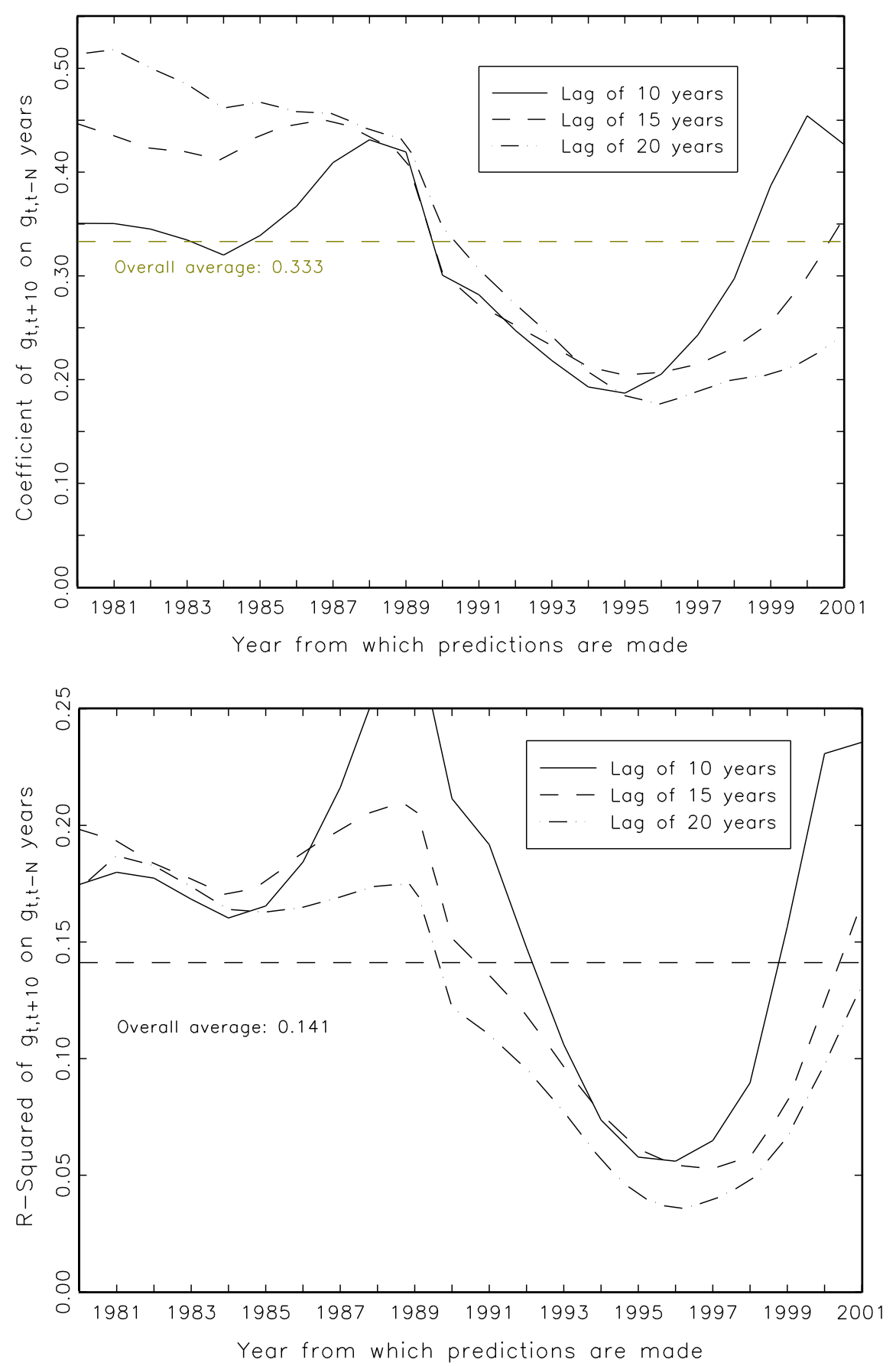

Source: Authors' calculations with PWT8.0 data. 


\subsection{Does economy or country size matter for persistence?}

China and India have continental scale in size and in population. In population, each was three times larger than the United States and twice as large as the European Union. This leads many to be skeptical as to whether their growth dynamics will be well-predicted from crossnational regressions which, even when excluding the tiny economies, contain countries with an average population less than a typical Indian or Chinese province. However, it is far from obvious that rapid growth episodes are more stable in larger economies measured by either total GDP or population; for example Brazil in 1980 and Japan in 1991, both very large countries, had massive decelerations from rapid growth to extended stagnation--not to mention the recent crisis in the United States.

This empirical question is difficult to address because the usual approach of allowing for interaction terms in size has one of two limitations. Either China and India are included in the regressions, in which case they are often influential data points, or they are excluded, which means that predictions from interactions of size have to extrapolate well out of sample. We choose the latter approach and extend our simple equation to allow for an interaction of persistence with size, now pooling across time.

(3) $g_{t, t+N_{f}}^{i}=\alpha+\beta * g_{t, t-N_{b}}^{i}+\gamma * \ln \left(y_{t}^{i}\right)+\delta * \ln \left(S_{t}^{i}\right)+\varphi * \ln \left(S_{t}^{i}\right) * g_{t, t-N_{b}}^{i}+\epsilon^{i}$.

As a proxy for size we use either total GDP in PPP or population. From samples excluding India and China the estimated coefficient $\varphi$ is negative and statistically significant, implying that large countries have less persistence. Using either proxy for size, the predicted annual growth rates for the coming decade for both China and India are in the 3 to 4 percent range. 


\begin{tabular}{|c|c|c|c|c|}
\hline \multirow[b]{2}{*}{$\begin{array}{l}\text { Proxy for size } \\
\text { used in equation } \\
3 \text { : }\end{array}$} & \multicolumn{2}{|c|}{ China } & \multicolumn{2}{|c|}{ India } \\
\hline & 10 years ahead & 20 years ahead & 10 years ahead & 20 years ahead \\
\hline $\begin{array}{l}\text { Ln(Total PPP } \\
\text { GDP) }\end{array}$ & 2.78 & 3.36 & 3.02 & 3.07 \\
\hline Ln(Population) & 3.34 & 4.18 & 3.68 & 3.87 \\
\hline
\end{tabular}

\section{3.) Asymmetry of persistence: Do booms last while busts revert?}

The question for China and India is primarily the persistence of an already extended episode of rapid growth. It is possible that the reversion to the mean on average is that countries

with busts - that is, episodes of low growth — tend to recover to the mean while episodes of rapid growth are more extended. We explore this possibility with the simple exercise of allowing the regression in each year to have a different coefficient for predicting future growth depending on whether the country's past growth is above or below the mean of past growth. Since China and India obviously have extended booms, we estimate these regressions without those two countries. The results, presented graphically in Figure 3, provide some support for asymmetry. On average for the period 1980-2011 the persistence coefficient was 0.442 for growth above the mean and 0.065 when country growth was below the mean. This suggests that busts were even less persistent than booms - for an extended period the coefficient on past growth was even modestly negative for countries with slow growth, suggesting full regression to the mean. 
Figure 3: Allowing for differential persistence for countries above and below the means shows that busts have, on average, been more rapidly mean reverting than booms (though not in the most recent years)

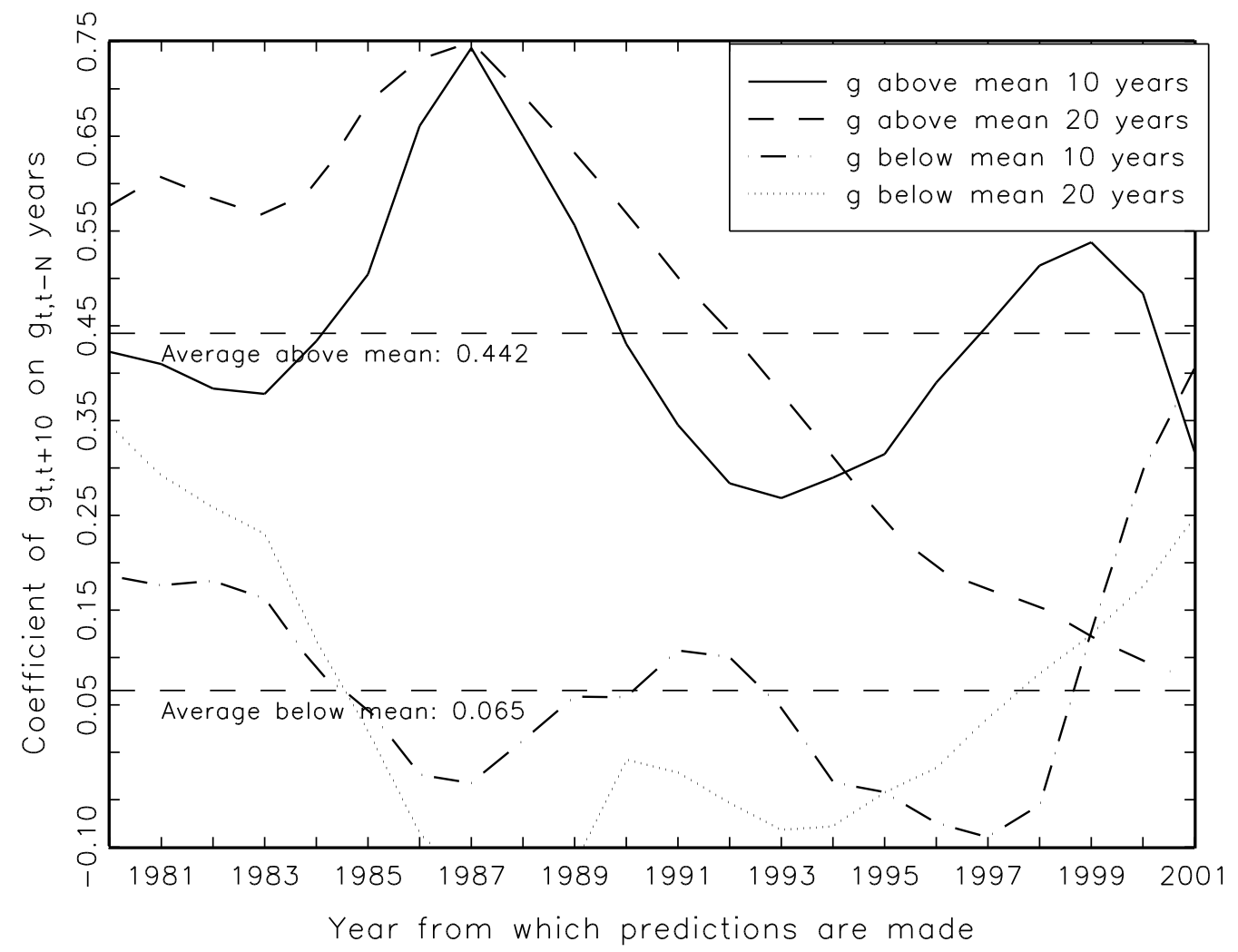

Source: Authors calculations with PWT8.0 data. 
It is unclear how this applies to predicting China's future growth as, using either growth lagged 10 or 20 years, the very most recent results suggest, if anything, the same or even less persistence of a boom. In any case, the highest persistence coefficient one could justify using is the period average of 0.44 for growth rates above the mean. All else equal, this would imply decade-ahead growth predictions of roughly 5 percent for China and 3.8 percent for India, assuming 2 percent world growth. These growth predictions are still well below the conventional forecasts.

\section{How long do episodes of rapid growth usually last? How do they end?}

From 1967 to 1980, Brazil's economy grew at 5.2 percent per year. While many people might have identified macroeconomic and structural imbalances putting that growth at risk of a recession or cyclical slowdown, no one in 1980 was predicting that for the next 22 years-from 1980 to 2002 - per capita growth would be almost exactly zero. We conjecture that nearly any assessment of the risk of such an extended slowdown using existing statistical methods for forecasting long-run growth would have found a 5.2 percentage point deceleration an extremely improbable outcome. In this section we examine episodes of growth to argue that, while not our modal forecast, the likelihood of a slowdown much larger than the regression to the mean-a socalled "sudden stop" — is a possibility.

The second main point of the Easterly et al. (1993) paper was that, while growth rates have low intertemporal persistence, the right-hand side variables of the then-popular growth regressions tended to have high persistence (on the order of 0.6 to 0.8 ). The obvious consequence is that at most a small part of the observed variation in growth rates could, even in 
principle, be explained by a linear relationship with an established set of determinants of growth and constant coefficients.

Hausmann, Pritchett, and Rodrik (2005) document the existence of frequent growth accelerations of substantial magnitude (more than 2.5 percent per year) to rapid growth. They show the timing of these growth accelerations are typically not well explained by standard growth determinants (e.g., good policy) or changes in the standard growth determinants (e.g., policy reform). ${ }^{12}$

An alternative to characterizing growth as a smoothly evolving function of linear determinants is to characterize the growth process as episodic, characterized by discrete shiftsaccelerations and decelerations - from one growth state to another (Pritchett 2000, Jones and Olken 2008). These discrete shifts in growth states produce large and then persistent changes in growth rates.

A recent set of papers extended the growth accelerations and decelerations approach to a complete characterization of the growth process of each country into a set of growth episodes (e.g., Kar et al. 2013). The basic procedure was to use the Bai-Perron approach to identify the years that best divided the GDPPC into distinct growth episodes each having a length of at least 8 years. Then a filter was applied to the magnitude of each potential Bai-Perron break year to eliminate the potential breaks that were empirically small changes in growth that did not

\footnotetext{
${ }^{12}$ Although Rodrik (1999) does a better job of explaining growth decelerations as a product of negative shocks and weak social ability to cope with shocks. McDermott and Breuer (2013) recently argue that the onset and timing of depressions are better empirically explained by bad policies than growth accelerations are by good. This is consistent with the argument of Easterly (1993) that many of the robust findings of the first generation of growth regressions were actually due to nonlinearities of sufficiently bad policy (e.g., high black market premium) producing very bad growth outcomes.
} 
represent substantial change in the growth process. ${ }^{13}$ The filter was a 2 percent difference in annual growth rates for the first potential break; for each subsequent break, if an acceleration followed an acceleration or if a deceleration followed a deceleration then 1 percent was deemed a break, and if an acceleration followed a deceleration (or vice versa) then a 3 percent change was deemed a break. This procedure divides each country's growth experience into a set of episodes from as few as zero (if the country experiences no growth breaks, as is the case for several OECD countries such as France and the United States) to as many as five, if all four possible Bai-Perron breaks pass the filter (as it does for, say, Argentina).

Figure 4 summarizes growth of India's real GDP per capita according to PWT7.1 data. ${ }^{14}$ This characterization of India's growth regime is an annual growth rate of 2.09 percent from 1950 to 1993 , quite near the world average of 2.15 percent. This is followed by an acceleration of growth to 4.23 percent from 1993 to 2002 , then a second acceleration of growth from 4.23 to 6.29 from 2002 to 2010 . In this set of episodes India has experienced a period of accelerated growth for 17 years (1993 to 2010) at a pace of 4 percent or higher. ${ }^{15}$

In the graphs the green line is the actual data, the turquoise line is the predicted growth allowing for splines at each of the identified growth episode transitions, and the red line is the growth if the country had grown at the predicted rate over each episode. In the left-hand panel the predicted growth is from a country/episode-specific regression that allows for regression to

\footnotetext{
${ }^{13}$ That is, we did not use the Bai-Perron tests of statistical significance to identify which potential breaks were true breaks as the statistical power varies so widely from country to country.

${ }^{14}$ The PWT8.0 was only recently available and the entire procedure has not been repeated with the new data, either using national accounts or PPP-adjusted data.

${ }^{15}$ There has been a great deal of debate over the dating of India's growth acceleration, and the results are sensitive to the data and method used. In particular, the choice of the length of an episode determines how a recent growth acceleration will affect the dates, as no acceleration can be near the fixed length from the end of the coverage of the data. While many date the acceleration near the adoption of the liberalizing reforms during and after the incipient macroeconomic crisis of 1990-91, Rodrik and Subramanian (2004) date the growth acceleration to the early $1980 \mathrm{~s}$ - well before the onset of those reforms. For our purposes the question is whether the recent acceleration to super high growth rates, which clearly took place in the $2000 \mathrm{~s}$ - will persist.
} 
the mean and (unconditional) convergence. For example, India's growth from 1993-2002 is predicted from a regression of growth in all other countries from 1993 to 2002 regressed on their growth over the previous episode of 1950 to 1993 and the level of GDPPC in 1993 and then plugging India's values of growth and level of GDPPC into that regression. This allows for shifts in global growth, duration, and period-specific regression to the mean and convergence (unconditional on anything except past growth). The right-hand panel just uses unweighted world average growth over the episode period as the "predicted" growth.

The same procedure applied to China in Figure 5 produces three accelerations in a row. Growth from 1968 to 1977 was 4.33 percent per year, accelerating to 7.61 percent from 1977 to 1991 and accelerating yet again in 1991 to 8.63 percent until 2010. (The graph goes off the top scale as these figures are produced for a large number of countries with a common vertical axis range in order to allow visual comparability). China has had growth rates of over 6 percent for 33 years starting in 1977, and this data set ends in 2010. 

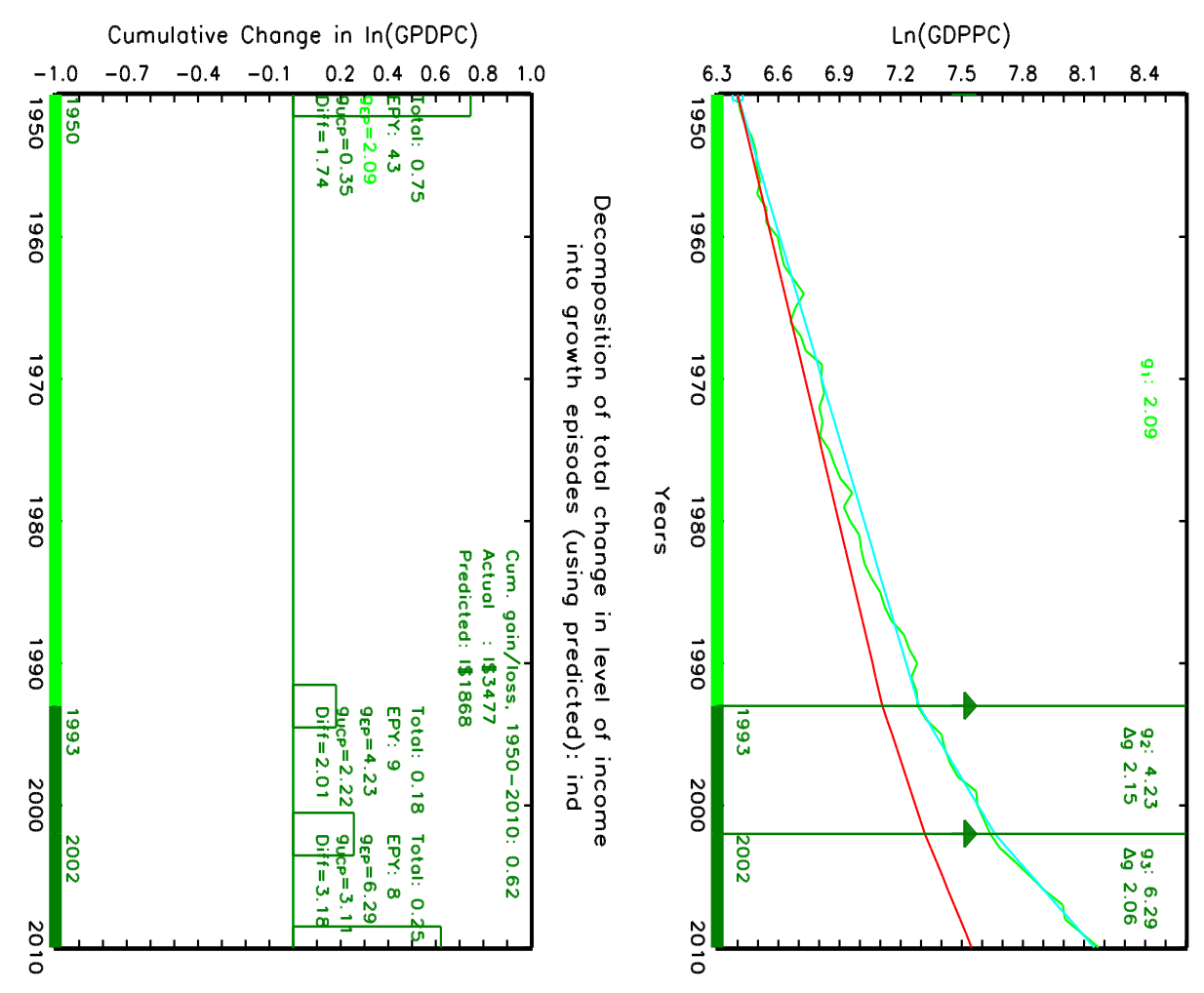

อัด
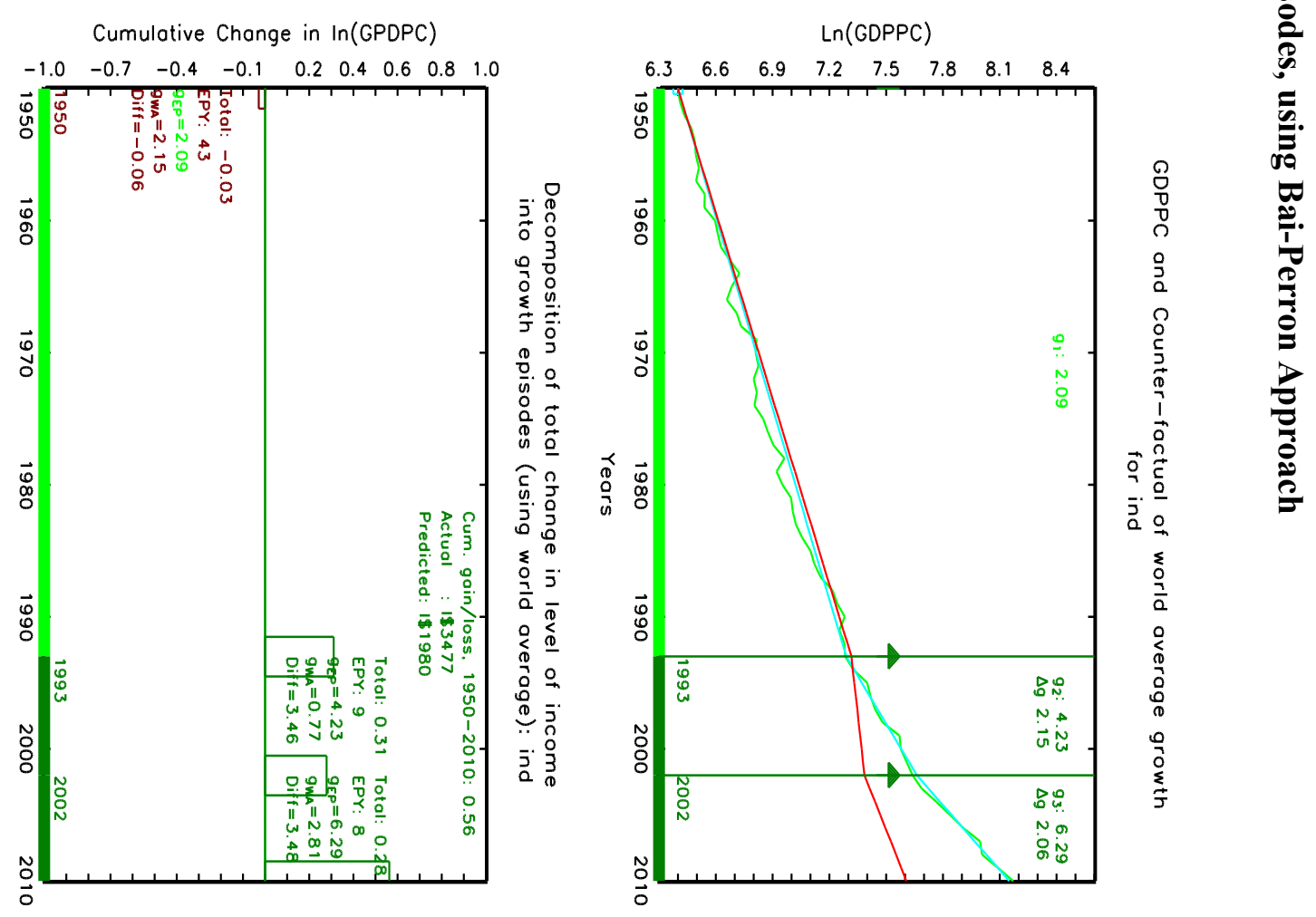

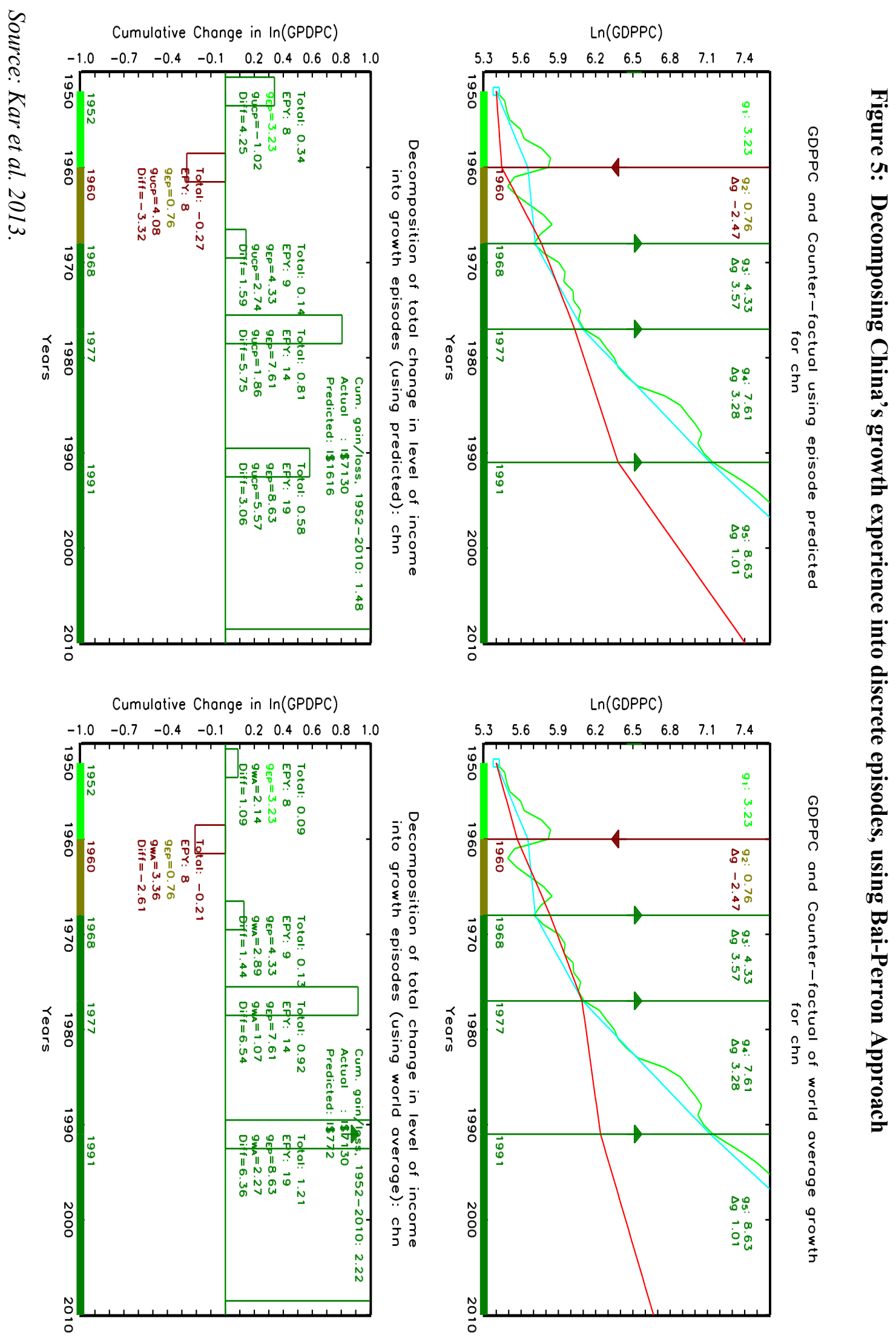
Speculation about how much longer China's and India's current episodes of rapid growth might last and what might happen after those episodes through comparison with all other experiences of country accelerations into rapid growth is informative but not dispositive. Table 9 shows all 28 growth recorded accelerations that resulted in episodes of growth higher than 6 percent per year (which is roughly two standard deviations above the cross-national mean). This table reveals how unusual China's (and to a lesser extent India's) current growth experiences are in three ways.

First, episodes of super-rapid growth ( $>6$ percent) tend to be extremely short-lived. The Kar et al. (2013) method of dating growth episodes mechanically does not allow for episodes of less than eight years. The median duration of a super-rapid growth episode is nine years, only one year longer than its possible minimum. There are essentially only two countries with episodes even close to China's current duration. Taiwan had a growth episode from 1962 to 1994 of 6.8 percent (decelerating to growth of 3.5 percent from 1994 to 2010). Korea had an episode from 1962 to 1982 followed by another acceleration in 1982 until 1991 when growth decelerated to 4.48 percent — a total of 29 years of super-rapid growth ( $>6$ percent) — followed by still rapid ( $>4$ percent) growth. So, China's experience from 1977 to 2010 already holds the distinction of being the only instance, quite possibly in the history of mankind, but certainly in the data, with a sustained episode of super-rapid ( $>6 \mathrm{ppa}$ ) growth for more than 32 years.

Second, the end of an episode of super-rapid growth is nearly always a growth deceleration. Of the 28 episodes of super-rapid growth, only two ended with a shift to higher growth: Korea in 1982 and China in 1991. So, again, China is remarkable in that its acceleration to super-rapid growth in 1977 was followed by another acceleration in 1991. 
Third, the typical (median) end of an episode of super-rapid growth is near complete regression to the world mean growth rate. The median of the growth episode that follows an episode of super-rapid growth is 2.1 percent per year. So the "unconditional" expectation (or central tendency) of what will happen following an episode of rapid growth, conditional on a shift in growth, is a reversion to not just somewhat slower growth but actually a massive deceleration of 4.65 percentage points. Such a slowdown is more than twice the cross-national standard deviation of growth rates of roughly 2 percent. A deceleration of that magnitude would take India's current growth episode of 6.29 to 1.64 percent and China's from 8.63 (in the episode since 1991) to 3.98 percent. 


\begin{tabular}{|c|c|c|c|c|c|c|}
\hline Country & $\begin{array}{l}\text { Year of } \\
\text { acceleration } \\
\text { to high } \\
\text { growth } \\
\text { episode } \\
(>6)\end{array}$ & $\begin{array}{l}\text { Year of } \\
\text { end of } \\
\text { Episode }\end{array}$ & $\begin{array}{l}\text { Duration } \\
\text { of } \\
\text { episode } \\
\text { (so far) }\end{array}$ & $\begin{array}{l}\text { Growth } \\
\text { during } \\
\text { high } \\
\text { growth } \\
\text { episode } \\
\text { (sorted) }\end{array}$ & $\begin{array}{l}\text { Growth } \\
\text { after end } \\
\text { of } \\
\text { Episode }\end{array}$ & $\begin{array}{l}\begin{array}{l}\text { Deceleration } \\
\text { (negative)/ }\end{array} \\
\text { Acceleration } \\
\text { (positive) to } \\
\text { next episode }\end{array}$ \\
\hline $\begin{array}{l}\text { Trinidad and } \\
\text { Tobago }\end{array}$ & 2002 & Continuing & 8 & $9.80 \%$ & & Continuing \\
\hline Gabon & 1968 & 1976 & 8 & $9.26 \%$ & $-2.66 \%$ & $-11.92 \%$ \\
\hline Angola & 2001 & Continuing & 9 & $9.24 \%$ & & Continuing \\
\hline Japan & 1959 & 1970 & 11 & $8.99 \%$ & $3.40 \%$ & $-5.59 \%$ \\
\hline China & 1991 & Continuing & 19 & $8.63 \%$ & & Continuing \\
\hline Korea & 1982 & 1991 & 9 & $8.40 \%$ & $4.42 \%$ & $-3.99 \%$ \\
\hline Jordan & 1974 & 1982 & 8 & $8.18 \%$ & $-4.35 \%$ & $-12.54 \%$ \\
\hline Singapore & 1968 & 1980 & 12 & $7.94 \%$ & $4.17 \%$ & $-3.78 \%$ \\
\hline Malaysia & 1970 & 1979 & 9 & $7.66 \%$ & $1.52 \%$ & $-6.14 \%$ \\
\hline China & 1977 & 1991 & 14 & $7.61 \%$ & $8.63 \%$ & $1.01 \%$ \\
\hline Laos & 2002 & Continuing & 8 & $7.59 \%$ & & Continuing \\
\hline Morocco & 1960 & 1968 & 8 & $7.25 \%$ & $3.85 \%$ & $-3.40 \%$ \\
\hline Portugal & 1964 & 1973 & 9 & $7.10 \%$ & $1.73 \%$ & $-5.36 \%$ \\
\hline Greece & 1960 & 1973 & 13 & $6.98 \%$ & $1.50 \%$ & $-5.48 \%$ \\
\hline Taiwan & 1962 & 1994 & 32 & $6.77 \%$ & $3.48 \%$ & $-3.29 \%$ \\
\hline Malaysia & 1987 & 1996 & 9 & $6.69 \%$ & $2.10 \%$ & $-4.59 \%$ \\
\hline Botswana & 1982 & 1990 & 8 & $6.65 \%$ & $2.80 \%$ & $-3.85 \%$ \\
\hline Ecuador & 1970 & 1978 & 8 & $6.55 \%$ & $-0.39 \%$ & $-6.94 \%$ \\
\hline Thailand & 1987 & 1995 & 8 & $6.51 \%$ & $1.85 \%$ & $-4.65 \%$ \\
\hline Ireland & 1987 & 2002 & 15 & $6.40 \%$ & $0.37 \%$ & $-6.03 \%$ \\
\hline Cambodia & 1998 & Continuing & 12 & $6.35 \%$ & & Continuing \\
\hline India & 2002 & Continuing & 8 & $6.29 \%$ & & Continuing \\
\hline $\begin{array}{l}\text { Dominican } \\
\text { Republic } \\
\end{array}$ & 1968 & 1976 & 8 & $6.29 \%$ & $1.01 \%$ & $-5.28 \%$ \\
\hline Korea & 1962 & 1982 & 20 & $6.27 \%$ & $8.40 \%$ & $2.14 \%$ \\
\hline Chile & 1986 & 1997 & 11 & $6.16 \%$ & $2.79 \%$ & $-3.37 \%$ \\
\hline Paraguay & 1971 & 1980 & 9 & $6.16 \%$ & $0.66 \%$ & $-5.50 \%$ \\
\hline Sierra Leon & 1999 & Continuing & 11 & $6.11 \%$ & & Continuing \\
\hline Cyprus & 1975 & 1984 & 9 & $6.04 \%$ & $3.81 \%$ & $-2.24 \%$ \\
\hline Median & & & 9 & $6.87 \%$ & $2.10 \%$ & $-4.65 \%$ \\
\hline
\end{tabular}


The results in Table 9 are not an artifact of classifying just super-rapid ( $>6$ percent) growth. If we look at all episodes of growth greater than 4 percent (one standard deviation above mean) we would find many more episodes but similar results about duration and deceleration in all three regards. The 70 episodes of growth above 4 percent (inclusive of those above 6 percent) also have a median duration of nine years. One does find more examples of extended rapid growth greater than 4 percent-Singapore with 30 years at 4.17 percent from 1980 to 2010 , Indonesia with 29 years at 4.71 percent from 1967 to 1996, Thailand with 29 years at 4.91 percent from 1958 to 1987 (followed by an acceleration), Vietnam with 21 years (and ongoing) at 5.54 percent. But still, other than the combination of Thailand's episodes (the first of which was at much lower rates than China's and the end of which precipitated the East Asian crisis of 1997), none of the episodes of even rapid growth ( $>4$ percent) is of longer duration than China's. In the 70 episodes of rapid growth ( $>4$ percent), there are only four cases in which the episode ended with a growth shift that was an acceleration (China in 1991, Korea in 1982, Thailand in 1987, and Botswana in 1982). Finally, the median growth in the episode following the rapid growth episodes is 1.85 percent. Again, the growth following an episode of rapid growth is, on average, full regression to the mean.

\section{1. $\quad$ Are Asian Giant growth dynamics driven by a middle income trap?}

In a set of influential papers, Eichengreen, Park, and Shin $(2012,2013)$ have argued for the existence of a middle-income trap. Their analysis identifies episodes of slowdown in middleincome countries as countries with an episode of growth greater than 3.5 percent followed by a growth deceleration of 2 percent or more, defining middle income by a level of PPP income of 10,000. Their 2012 paper suggested a mode in the distributions of slowdown around PPP15,000-16,000. Their 2013 update using the new PWT7.1 data with more observations 
altered both their identifications of the growth breaks, modified some conclusions, and added some insights. First, they find less evidence of a single mode and more suggestion of two modes of slow-downs, one at PPP10,000-11,000 and another at PPP15,000-16,000. Second, they examine the correlates of slowdowns and find that education of secondary and higher levels (conditional on GDP per capita) and high technology exports mitigate the risks of slow down.

The Eichengreen, Park, and Shin $(2012,2013)$ analysis focuses only on those decelerations among countries that are middle income and hence they limit their sample to decelerations among countries that are already near middle income. The middle-income trap conjecture almost certainly has no bearing on India, which is and will remain for the foreseeable future a poor country. The PWT8.0 estimate of Real GDP (expenditure) per capita is $\$ 3755$ - which is only 8.4 percent of the U.S. level.

We replicate a version of the middle-income trap analysis by taking all structural breaks identified by the Kar et al. (2013) and looking at those that are decelerations. We regress a dummy variable for a country-year pair that was (near) a deceleration on either the ratio of country's GDPPC to the United States' (as a proxy for the global leader at the time) or on the absolute level of GDPPC and also include the growth in the episode preceding the deceleration. To allow for a flexibly specified relationship, we estimate this simple bivariate relationship using quartic terms in either the ratio or level.

Figure 6 (ratio to US GDPPC) and Figure 7 (level of GDPPC) present the predicted probability of a deceleration against either the ratio to US GDPPC or absolute GDPPC. There are three lines showing the relationship with the ratio or level of GDPPC at average growth, at China's growth, and at India's growth. 
The graph makes the basic point that the main issue with China and India is that their likelihood of deceleration is currently mainly influenced by the fact that they are growing very rapidly as there is a strong association of pace of growth with the likelihood of deceleration. So, while there may, or may not, be a middle-income trap, empirically the change in the likelihood of deceleration associated with changes in income as countries grow is small compared with the association of rapid growth.

Take China. The predicted likelihood of a deceleration of a country with average growth at China's 2011 level of GDPPC of $\$ 7,110$ is 4.5 percent (using PWT7.1 since the structural breaks were done with that data). At $\$ 20,000$ (roughly the maximum with respect to level of income) that risk increases to 5.7 percent — so there is some modest middle-income trap dynamic of increased likelihood of deceleration with increased income. By contrast the predicted likelihood of deceleration at China's current level of growth and level of income is 14.4 percent. This increases to 15.7 percent at $\$ 20,000$. So, the increase in the predicted likelihood of a deceleration due to China's higher than average growth is roughly 10 times larger than the increase from increasing GDPPC from its current level to the biggest risk due to middle-income trap dynamics. 
Figure 6: Regression of deceleration on country/year ratio to USA GDPPC (quartic)

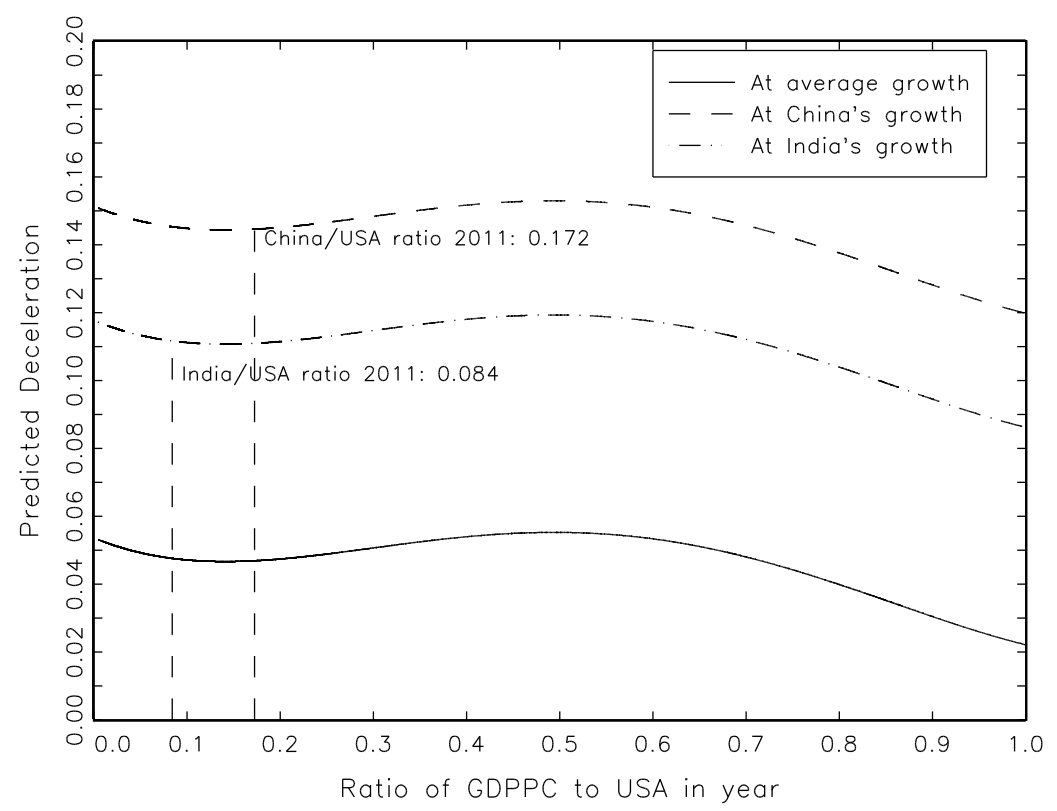

Source: Author's calculations with Kar et al. (2013) structural breaks

Figure 7: Regression of deceleration on absolute level of GDPPC (quartic)

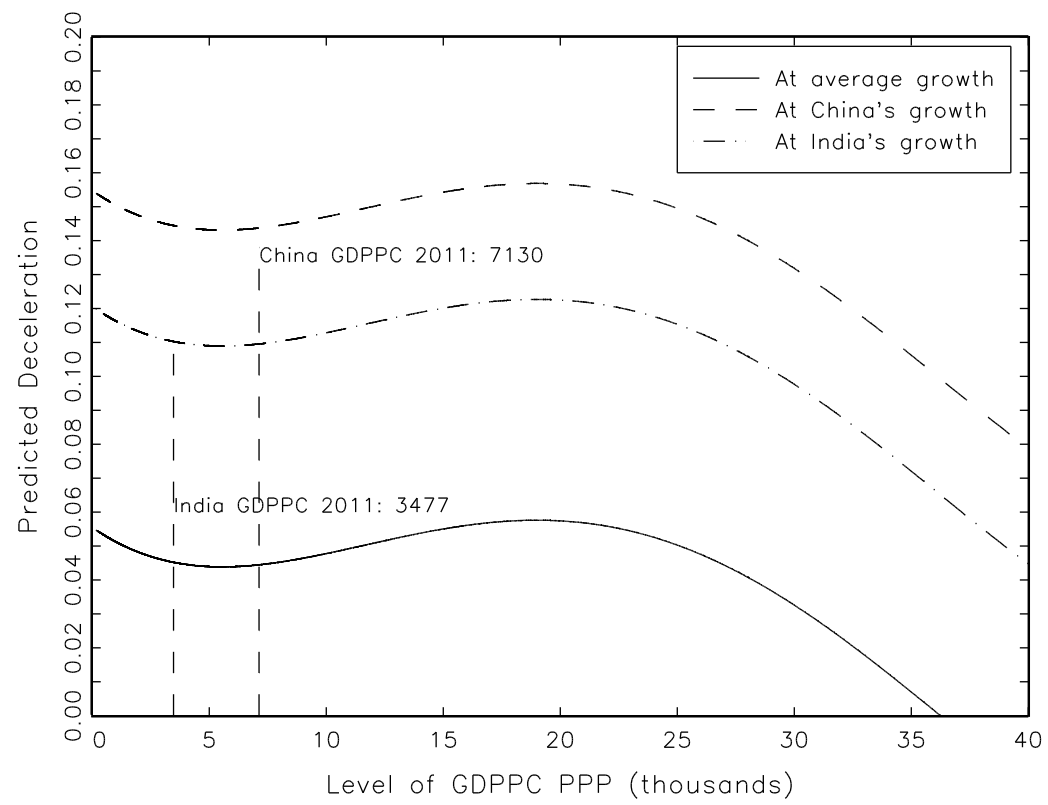

Source: Author's calculations with Kar et al. (2013) structural breaks 


\section{China's challenge: Stable rule of power into rule of law}

So far our discussion of the Asian Giants as an engine of global growth has been remarkably free of any discussion of the specifics of the Asian Giants. One might have expected the question of whether Asia can be the engine of future global growth, to have been addressed by specifying some relationship between growth and its proximal or causal determinants of the type

$$
g=f(x)
$$

and then making the case for continued rapid growth or deceleration based on that model and the likely trajectories of the " $x$ " variables - like the outcome of "policy reform." While we will engage in some country-specific discussion along those lines below, we deliberately choose not to go that direction for three reasons.

First, conditional forecasting of this type is only as good as the forecasts of the conditioning variables. Imagine dividing the potential $x$ 's into two types: those easy to forecast because they have high persistence (e.g., size of the country, geography, latitude, nearness to ports) and those with low persistence. Obviously the former are quite easy to forecast, but also cannot be the usual causes of super-rapid growth. That is, since serial correlation of growth is low in the data, then constant determinants of growth cannot have high explanatory power.

The growth determinants with low persistence may be good at forecasting growth but are themselves harder to forecast. Again, by construction, extrapolation of those variables is a bad forecast of $x$, making a forecast conditional on $x$ a bad forecast. To use this forecast, continued rapid growth would then require that we somehow have a good forecast that some important growth determinant is going to change in such a way that growth that otherwise would have 
decelerated remains rapid. We cannot think of such a thing and, as we argue below, there are several prominent possibilities of just the opposite dynamic.

Second, even if we could reliably forecast the $x$ 's we would also need to identify a reasonably accurate and long-term stable empirical relationship. This just has not been true to any extent in the domain of economic growth, nor is this unique to economic growth. We have lived through a series of major political, social, and economic events in our lifetime, none of which were widely predicted by experts in the appropriate domain.

A salient recent example is that we are still living in the shadow of the financial crisis in the United States and elsewhere. The depth and severity of the crisis was not predicted by academic economists on the sidelines or in their assessments of the riskiness of classes of assets, nor by raters (Silver 2012), nor by policymakers. People with most of their financial wealth at risk still misforecast the outcomes in the housing market badly, even though they should have had very high stakes to forecast correctly. This is not because there was ignorance of a housing bubble; some mainstream economists (particularly Robert Shiller among others) pointed out the magnitude of the deviation of housing prices from their long-run trends early (at least by 2005) and often. But what was missed was how this would impact the financial sector and the economy as a whole. Leamer's (2010) demonstration of how the evolution of prices and quantities in the Los Angeles housing market produced enormously different dynamics in different periods, such that the confidence intervals based on past data for future predictions substantially understated the true range of possibility is just one example of the instability of models. 
Third, super-rapid growth is due in part to a large residual or unexplained component, which we rarely admit as we overexplain the current reality. That is, we concoct reasons ex-post to make it seem as if we understand what happened when we really did not. While perhaps too much can be made of Taleb's (2007) “Black Swan” arguments that we overpredict reality, conventionally, too little is made of them. Taleb's obvious and poignant example was that, while Lebanon remained an oasis of multireligious peaceful coexistence and institutional success (believed to be "the Switzerland of the Middle East") there were many powerful theories to suggest that Lebanon's success was overdetermined by observable factors. And then, after Lebanon was engulfed by the general regional instability, it quickly became equally obvious that Lebanon was doomed to instability.

Dramatic changes in perceptions of the Japanese economic system provide another example. During the late 1980s, it was widely believed that Japanese-style industrial policy, Japanese emphasis on corporate linkages through keiretsu, and high levels of investment supported by financial repression were keys to rapid growth. A decade later, the conventional wisdom held nearly the opposite views.

At an even broader level, it was widely believed in the early 1960s that the Soviet Union would quite likely outstrip the United States economically based on an extrapolation of its recent growth performance. Justifications were even developed for the apparently rapid growth of central Europe as late as 1979, as illustrated by the famous World Bank Report of that year on the Romanian economic miracle.

This point holds for countries as well. We believe that in the United States there are no known examples since 1950 when the consensus forecast called for recession one year out, even 
though recessions have occurred on average every five or six years since then and even though they appear to have a permanent rather than a temporary impact on output.

Imagine that in a conference in 2023 we know ex post that in 2014 China's GDPPC growth was 8 percent for the calendar year 2014. However, we also know that in March 2015 China experienced a sudden sharp slowdown in economic growth that persisted and caused growth to be only 2 percent from 2015 to 2023 . Here is the question: in that scenario, what do we think was the forecast of growth 2015-2023 in the IMF World Economic Outlook for China six months before the slowdown? Our guess is that the 2014 forecast was 8 percent growth and was expressed with substantial confidence.

All that said, we suspect that the reasons slowdowns will come in China and India are similar but will manifest themselves differently given the very different politics. That is, in neither country does investor confidence rely on rule of law. In both countries, there are plausible scenarios which may disrupt the current political settlement that provides a climate for ordered deals (Hallward-Driemeier and Pritchett 2011). This disruption could easily create processes with nonlinear sudden stops.

As North, Wallis, and Weingast (2009) show, the reason for the low growth on average of developing versus developed countries is not the lack of rapid growth — it is the lack of the growth persistence and the very low growth rates during their periods of negative growth. As we saw with Denmark, the rich industrial countries are rich because they grew at modest rates for very long periods, with little variation and few disastrous downturns-e.g., 84 percent of years in positive growth, and negative growth only falling to -2.33 percent per year. By contrast, current poor countries have failed to converge because they grow much faster when they are growing 
(e.g., 5.39 percent per year for those in the 2,000 to 5,000 range) then a third of their time have sizeable negative growth (averaging -4.75 percent for the same grouping).

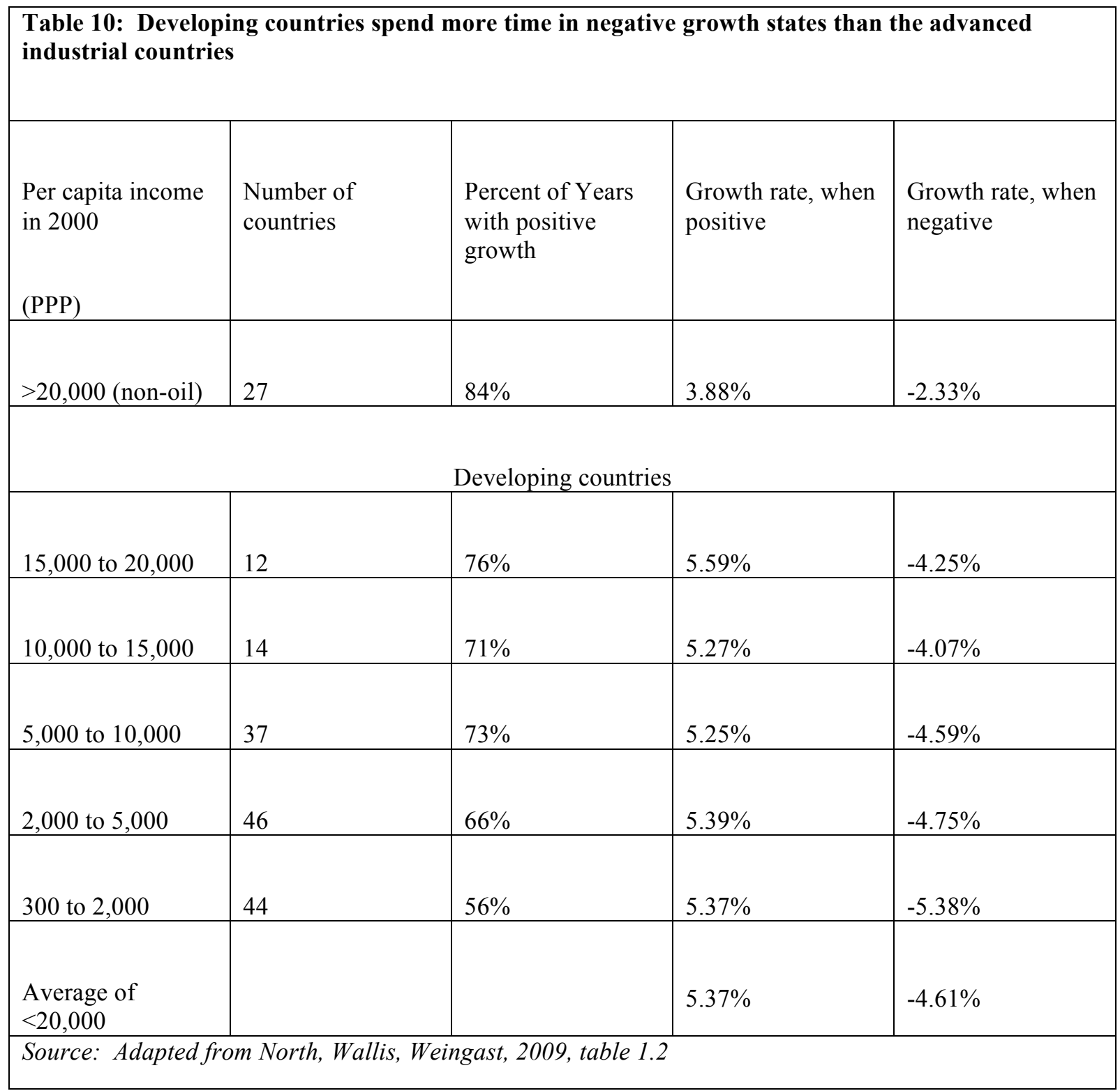

Take for example the comparison of the rich countries with those countries with a per capita income between $\$ 2,000$ and $\$ 5,000$. Average growth is equal to the average growth when positive times the probability that growth is positive plus average growth when negative times 
the probability of growth being negative. For both groups, average growth when positive contributes just about 3.6 percent to the weighted average. But for poorer countries, average growth when negative contributes -1.6 percent rather than -0.4 percent, accounting for all the difference in growth.

Powerful evidence suggests that high levels of output per capita are associated with high levels of institutional quality (e.g., Hall and Jones 1999, Acemoglu, Johnson and Robinson 2001, North, Wallis and Weingast 2009) and that, over very long periods, this association is sustained so that institutional arrangements can have very long-lasting effects (including regional evidence within countries as in Dell (2010) showing the persistence on levels of income and well-being today in Peru and Bolivia of the mita arrangements in Spanish colonial times). This view can accommodate short-run growth booms and busts driven by exogenous factors like terms of trade or new opportunities that do not challenge existing economic and political interests. However, it is very difficult (but perhaps not impossible) to explain the location, onset, or timing of extended growth episodes in terms of institutions because that component of income explained by events centuries ago (whether that is mita or crop endowments or settler mortality or social capital) should not be expected to handle large and rapid changes in income.

One conjecture about the source of growth slowdowns is that in countries with weak capability for implementation of policies there is a large divergence between the de jure laws and regulations and the de facto outcomes for specific firms. This can come in the form of arrangements that allow for high and secure profitability for firms without the neutral enforcement of the rule of law. It can even be the case that "closed ordered deals" (HallwardDreimeier and Pritchett 2011) that are provided for the favored firms are not only a good investment climate for doing business but a veritable greenhouse - that is, the environment 
specific to the firm (and its connections to existing power structures) is much better than the existing de jure regulatory environment and better than a de facto environment even with good regulations. That is, the favored firms in a closed order deals environment have higher and more secure profitability than the typical firm in an OECD country. As firms either "sieze the state" (Hellmann, Jones and Kaufmann 2000) or are the state or are chosen by the state (Fisman 2001), the official legal and regulatory environment — or more particularly its implementationare bended to provide great, if super-local and specific, conditions for growth. That is, growth in closed ordered deals can be much higher than in an institutionally good investment climate.

But, the difficulty is the transition. Since investor expectations (both domestic and foreign) are grounded in specific relationships to specific power bases, shifts in power can precipitate very sudden stops as investor expectations have to realign to new realities. This can create sudden stops that then can resume as new conditions are established or can persist for a very long time if new institutions have to emerge and have credibility.

This can lead measures of institutions - like those that measure political institutions - to be associated with the range of growth outcomes, not necessarily the level of growth over mediumrun periods. Figure 8 shows the largest difference in growth rates over 10-year periods of countries at various levels of the Polity score (which measures autocracy/democracy on a -10 to +10 scale). While autocracies can maintain very high growth rates - even over extended periods - they also tend to have much larger ranges of growth outcomes - with booms and busts - than stable democracies. 
Figure 8: Lower Polity scores are associated with larger changes in growth over time

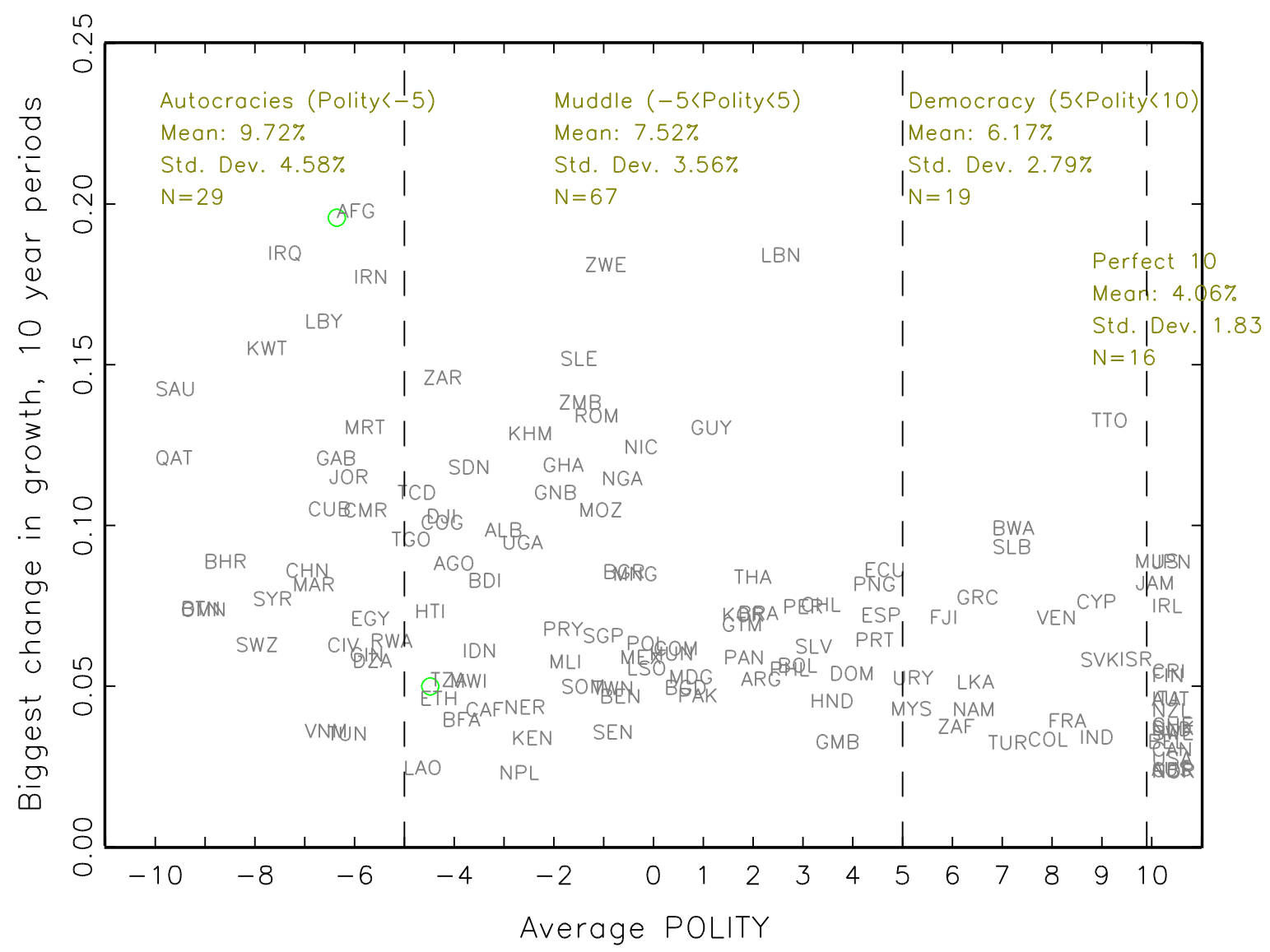

Source: Pritchett and Werker (2012).

There is a strong cross-national relationship between the extent to which a country is (or is rated as) a democracy and GDP per capita. This relationship reveals nothing about cause and effect, and certainly we are not going to assert some strong, mono-causal, linear dynamic whereby richer countries naturally become more democratic. That said, Figure 9 shows the relationship between a stock-like measure of democratic capital index that cumulates the Polity score into a stock (to smooth the transitory fluctuations) which then scales most the democratic countries as 100 and the least democratic countries as 0 . 
The obvious point is that there are extremely few exceptions to the tendency for all countries with high levels of GDP per capita (expressed here as an index from 0 to 100) to also have high levels of (measured) democracy. The only two exceptions for a country with GDPPC more than a third of the leader (33 on the index) not having a democracy capital score above 80 are Oman (an oil producer) ${ }^{16}$ and Singapore. For countries in China's current range of output (between 10 and 25 on scale of 0 to 100), the complete range of democracy outcomes exist. However, the average for this group is a democracy capital index of 71 with a standard deviation of 25 . Already at a score of 14 , China is much less democratic than the typical country with its level of output.

For China, continuing to have rapid economic growth while maintaining its current level of democracy (as proxied by its Polity score) — a trajectory moving rapidly due east in Figure 9would make it more and more anomalous. This is not to say it is not possible. Singapore (granted, a small city-state of only 5 million people) has managed to be nearly the richest country in the world while only having a Polity democracy capital index of 40 . But even 40 is more than twice China's current level of 14.

An empirical question is, what effect, if any, might we expect a democratizing period to have on China's growth?

\footnotetext{
${ }^{16}$ The nature of the data selection process used also excluded most other oil countries that would have had high income but low democratic capital because they lacked sufficient data.
} 
Figure 9: Relationship between GDP per capita and a stock of Democracy Capital Index in 2008 (both normed 0 to 100)

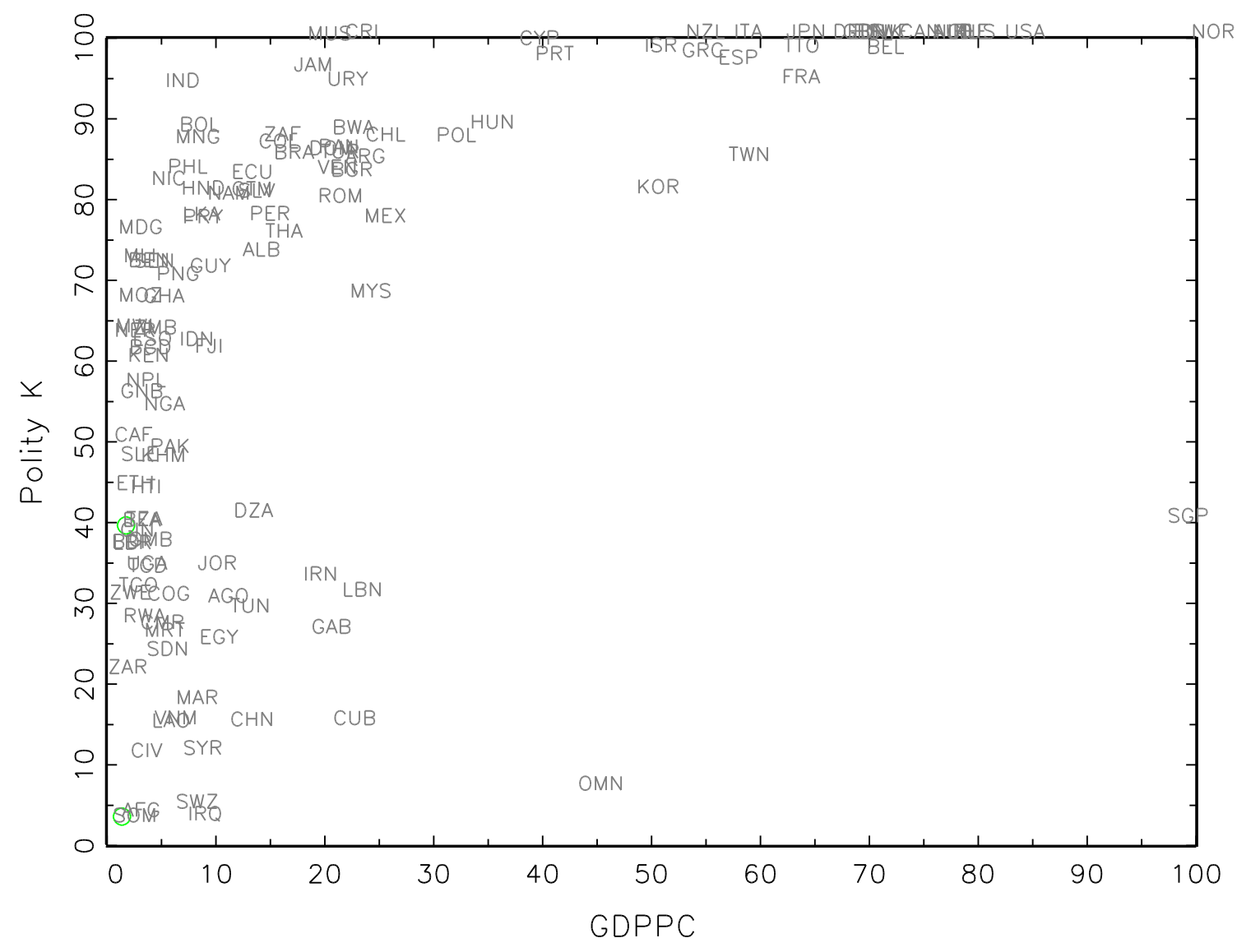

Source: Kenny and Pritchett 2013.

A huge literature examines the association between democracy and growth, and generally notes only a weak and non-robust association between the level of democracy and the pace of growth, but finds that less-democratic countries tend to have much higher volatility of growth. However, a simple analysis of whether democracies grow faster or slower than non-democracies does not capture the possibility that large political transitions may themselves have impacts. In this case, while democracies may be capable of sustaining rapid growth in the long run, the 
transition itself may create an adjustment period of slow growth. To examine this question, we need to compare countries' growth rates before and after large, rapid political transitions from autocracy to democracy. For this, we need to define what qualifies as "large" democratizing transitions.

Pritchett (2011) searched the Polity data to identify all instances when a country's index increased by more than five units in a single year towards less autocracy or more democracy. These were the candidates for large democratic transitions. He then used a decision tree to classify and date these potential transitions, addressing in particular the treatment of countries with multiple transitions. This classification scheme resulted in 52 episodes of large democratic transition. Once large democratic transitions had been identified, the next step was to calculate growth rates before and after the transition. To capture the medium- to long-run dynamics term (and exclude the short-run disruptions immediately before and after) he calculated the growth rate for the 10-year period ending three years before the transition and that for the 10 -year period beginning one year after the transition (or, if 10 years of data was not available, the period until the data ended). For instance, in the case of Indonesia, the two 10-year periods would be 198696 (the period ending three years before the democratic transition in 1999) and 2000-07 (the period beginning one year after the transition and ending when the PWT6.3 data stop in 2007). ${ }^{17}$

The first result evident in Table 11 is that nearly every country that experienced a large democratic transition after a period of above-average growth (more than the cross-country

\footnotetext{
${ }^{17}$ These timing assumptions are not innocuous. Often a political transition is preceded by a large fall in GDP per capita, sometimes as the result of the chaos surrounding the transition itself. If one then calculated the growth before the transition to include this fall (which could be the result of the transition itself), then it would look as though the political transition had accelerated growth. That is why we go back some years before the transition, so that the pure disruption effects are not counted as part of the pre-democratic period. Rodrik and Wacziarg (2005) obtain similar results overall: of the nine countries they identify with democratizing transitions begun from above 2 percent growth, the average deceleration is 3.53 percent, which is exactly what we find in Table 9. But in some countries timing differences produce different results.
} 
average of 2 percent) experienced a sharp deceleration in growth in the 10 years following the democratizing transition. Among 22 countries in which episodes of large democratic transition coincided with above-average growth, all but one (Korea in 1987 with an acceleration of only 0.22 percent) experienced a growth deceleration. The combination of high initial growth and democratic transition seems to make some deceleration all but inevitable. The magnitude of the decelerations was very large: The median deceleration across the 22 countries was 2.99 percent and the average deceleration was 3.53 percent. 
Table 11: Countries with large democratic transitions starting from above-average ( 2 percent per year) growth in GDP per capita ${ }^{\text {a }}$

\begin{tabular}{|c|c|c|c|c|c|}
\hline Country & $\begin{array}{l}\text { Year of } \\
\text { transition }\end{array}$ & $\begin{array}{l}\text { Magnitude } \\
\text { of Polity } \\
\text { increase }\end{array}$ & $\begin{array}{l}\text { Growth in } 10 \text {-year } \\
\text { period ending three } \\
\text { years before } \\
\text { democratizing } \\
\text { transition } \\
(\%)\end{array}$ & $\begin{array}{l}\text { Growth in } 10 \text {-year } \\
\text { period beginning } \\
\text { one year after the } \\
\text { transition } \\
(\%)\end{array}$ & $\begin{array}{c}\text { Change in pre- } \\
\text { /post-transition } \\
\text { growth rates } \\
(\%)\end{array}$ \\
\hline Greece & 1975 & 7 & 7.19 & 0.02 & -7.17 \\
\hline Iran & 1979 & 10 & 7.11 & 0.11 & -7.01 \\
\hline Portugal & 1976 & 6 & 7.11 & 1.48 & -5.63 \\
\hline Taiwan & 1992 & 8 & 6.47 & 3.95 & -2.52 \\
\hline Taiwan & 1987 & 6 & 6.42 & 5.78 & -0.64 \\
\hline Nigeria & 1979 & 7 & 5.81 & -2.44 & -8.25 \\
\hline Ecuador & 1979 & 14 & 5.69 & -1.66 & -7.36 \\
\hline Congo & 1992 & 6 & 5.68 & 0.57 & -5.11 \\
\hline Indonesia & 1999 & 11 & 5.54 & 3.28 & -2.26 \\
\hline $\begin{array}{l}\text { Dominican } \\
\text { Republic }\end{array}$ & 1978 & 9 & 5.50 & 1.35 & -4.14 \\
\hline $\begin{array}{l}\text { South } \\
\text { Korea }\end{array}$ & 1987 & 6 & 5.36 & 5.57 & 0.22 \\
\hline Thailand & 1992 & 10 & 4.67 & 0.82 & -3.85 \\
\hline Mongolia & 1990 & 9 & 4.39 & 2.09 & -2.30 \\
\hline Bulgaria & 1990 & 15 & 4.02 & -0.10 & -4.12 \\
\hline Panama & 1989 & 16 & 3.91 & 1.68 & -2.23 \\
\hline Benin & 1990 & 7 & 3.62 & 1.30 & -2.32 \\
\hline Pakistan & 1988 & 12 & 3.50 & 1.32 & -2.18 \\
\hline Uruguay & 1985 & 16 & 3.44 & 3.16 & -0.27 \\
\hline Brazil & 1985 & 10 & 3.31 & -0.34 & -3.65 \\
\hline Paraguay & 1989 & 10 & 2.70 & -0.75 & -3.45 \\
\hline Bolivia & 1982 & 15 & 2.37 & 0.27 & -2.09 \\
\hline Romania & 1989 & 6 & 2.14 & 0.85 & -1.28 \\
\hline Median & & & 5.01 & 1.08 & -2.99 \\
\hline Average & & & 4.82 & 1.29 & -3.53 \\
\hline
\end{tabular}

Source: Pritchett (2011). 
At least one mechanism that could cause democratizing transitions to decelerate growth has been explored in the case of Indonesia. As Fisman (2001) has shown, the stock market value of firms connected to President Soeharto was associated with news about his health, implying that a substantial amount of their value was related to his personal control of the levers or power. While power in China is obviously controlled by much larger and broader regionally competing forces, it nevertheless is not exercised in what one would typically call a democratic fashion nor according to the rule of law or traditionally conceived human rights. That said, the fact that China is rated by most indicators as having very low control over corruption and not having improved over the previous decade has obviously not been an obstacle to rapid growth. This is not surprising as Shleifer and Vishny (1993) have long argued that organized corruption need not be inimical to growth. However, it is difficult for corruption to remain organized during a transition in political power.

We are not forecasting that China will move towards democracy nor that this will be what causes China's growth to slow. But we are pointing out the very dangerous shoals through which the Chinese economy is currently sailing very rapidly. While it is possible to envision the transition not happening for some extended time and while it is possible to envision the transition being made smoothly, neither of these is the outcome typically observed in the data.

\section{Conclusion}

Much analysis and forecasting regarding economic growth treats a country's individual history as the principle means by which to think about its future. It is an empirical question whether this is right or wrong. Someone looking to predict the future health status of a 60 -yearold would give some weight to her health history but probably much more weight to the 
available information on the past populations of 60 -year-olds. In the same way, our findings suggest that in forecasting growth rates over the long term, forecasters should give heavy weight to the growth rate of all countries. We believe that most economic forecasting errors historically have come from neglecting this principle and placing excessive weight on a country's recent past in making forecasts. Perhaps this is why official forecasts usually miss discontinuities.

The recovery in the United States is currently slow relative to expectations, and the recovery in Europe is even weaker. Yet, the post-crisis fallout for the global economy has been much less than feared. This has certainly been due in large part to sustained growth in China and India that likely has positive spillovers (e.g., through high commodity prices and trade linkages) to other economies. The hopeful and in many quarters prevailing view is that this represents a decisive shift and that rapid global growth will continue - and perhaps even OECD growth will recover - with Asia as the engine, via the Asian Giants and others.

This is certainly one scenario.

However, those the authors' ages or older remember well at least two previous periods of Asiaphoria. Japan's rapid growth from the 1960s (though decelerated already by the 1970s) led to popular and academic literature explaining why Japan succeeded and would continue to succeed. Although there were some concerns about a bubble in Japanese real estate, almost no one predicted in 1991 that Japan's real GDP per capita would be only 12 percent higher in 2011 than 20 years earlier (an annual growth rate of only 0.6 percent) and that total factor productivity in Japan, which had doubled from 1961 to 1991 would be 6 percent lower in 2011 than in 1991 (data and calculations from PWT8.0). 
The second Asiaphoria was the growth in the 1990s when Southeast Asian countriesIndonesia, Malaysia, and Thailand appeared to be booming along with the Four Dragons.. A financial and economic crisis spread across East Asia in the late 1990s with sharp contractions in nearly all the booming economies. While most recovered quicky, the annual growth rates for the most recent episode of growth have been only 1.42 percent for Indonesia, 2.1 percent for Malaysia, and 1.85 percent for Thailand, which is a relatively tepid growth from a quite steep contraction. Korea and Taiwan had shorter crises and quicker recoveries but their growth rates in the more recent growth episode are 3.48 and 3.29 percent, respectively, which is rapid but nothing like the current growth of China or India.

Regression to the mean is the single most robust finding of the growth literature, and the typical degrees of regression to the mean imply substantial slowdowns in China and India relative even to the currently more cautious and less bullish forecasts.

India and, even more so, China are experiencing historically unprecedented episodes of growth. China's super-rapid growth has already lasted three times longer than a typical episode and is the longest ever recorded. The ends of episodes tend to see full regression to the mean, abruptly.

It is impossible to argue that either China or India has the quality institutions that have been associated with the steady dynamic of growth in the currently high productivity countries. The risks of sudden stops are much higher with weak institutions and organizations for policy implementation. China and India have very different modalities of this risk, but both have tricky paths to continued prosperity. 
We suggest several implications of these conclusions. First, there will be a strong tendency to assume that, if growth slows substantially in China or India, it will represent an important policy failure. This is not right. Regression to the mean in a decade or so is the rule, not the exception. What would require much more explanation would be continued rapid growth, which would be very much outside the general run of experience. Second, those making global projections should allow a very wide confidence interval with respect to growth for countries whose current growth rates are far from the mean. Given the sensitivity of commodity demands in particular to growth rates in Asia, this suggests substantial uncertainty about the medium-term path of commodity prices. In the same way, forecasts of global energy use and climate change impacts should also recognize the possibility of discontinuities in Asia. Third, much geopolitical analysis has focused on the implications of a rising China, and certainly Chinese international relations theorists have extensively studied past rising powers. Contingency planning should also embrace scenarios in which Chinese growth slows dramatically, presumably bringing with it a range of domestic and international political implications. 


\section{References}

Acemoglu, Daron; Simon Johnson and James Robinson. 2001. "The Colonial Origins of Comparative Development: An Empirical Investigation." American Economic Review, 91(5), 1369-401.

Aguiar, Mark; Gopinath, Gita. 2007. "Emerging Markets Business Cycles: The Cycle Is the Trend." Journal of Political Economy, 115, 69-102.

Bank, World. 2012. China 2030: Building a Modern, Harmonious and Creative Society. Washington DC: World Bank.

Barro, Robert. 1991. "Economic Growth in a Cross Section of Countries." Quarterly Journal of Economics, 102(2), 407-43.

Breuer, Janice Boucher; McDermott, John. 2013. "Economic Depression in the World." Journal of Macroeconomics, 38(PB), 227-42.

Dell, Melissa. 2010. "The Persistent Effects of Peru's Mining Mita." Econometrica, 78(6), 1863-903.

Easterly, William; Michael Kremer; Lant Pritchett and Lawrence Summers. 1993. "Good Policy or Good Luck: Country Growth Performance and Temporary Shocks." Journal of Monetary Economics, 32(3), 459-83.

Eichengreen, Barry; Park, Donghyun; Shin, Kwanho. 2013. "Growth Slowdosn Redux: New

Evidence on the Middle Income Trap." NBER Working Paper No. 18673. . 2012. "When Fast Growing Economies Slow Down: International Evidence and Implications for China." Asian Economic Papers, 11, 42-87.

Feenstra, Robert C.; Inklaar, Robert; Timmer, Marcel. 2013. "The Next Generation of the Penn World Table."

Fisman, Raymond. 2001. "Estimating the Value of Political Connections." The American Economic Review, 91(4), 1095-102.

Fogel, Robert. 2010. "123,000,000,000,000." Foreign Policy, (December 20, 2010).

Greenspan, Alan. 2013. The Map and the Territory: Risk, Human Nature and the Future of Forecasting. New York NY: Penguin Press.

Hall, Robert and Charles I Jones. 1999. "Why Do Some Countries Produce So Much More Output Per Capita Than Others?" Quarterly Journal of Economics, 114(1), 83-116.

Hallward-Driemeier, Mary and Lant Pritchett. 2011. "How Business Is Done and the 'Doing Business' Indicators: The Investment Climate When Firms Have Climate Control," Washington DC: World Bank, Hausmann, Ricardo; Lant Pritchett and Dani Rodrik. 2005. "Growth Accelerations." Journal of Economic Growth, 10(5), 303-29.

Hellman, Joel; Jones, Geraint; Kaufmann, Daniel. 2000. "Sieze the State, Sieze the Day: State Capture, Corruption, and Influence in the Transition." World Bank Policy Research Working Paper No. 2444.

Jones, Benjamins and Benjamin Olken. 2008. "The Anatomy of Stop-Start Growth." Review of Economics and Statistics, 90(3), 582-87.

Kar, Sabyasachi; Pritchett, Lant; Raihan, Selim; Sen, Kunal. 2013. "Looking for a Break: Identifying Transitions in Growth Regimes." Journal of Macroeconomics, 38(PB), 151-66.

Kenny, Charles; Pritchett, Lant. 2013. "Promoting Millennium Development Ideals: The Risks of Defining Development Down " Center for Global Development, Working Paper, (338).

Leamer, Edward. 2010. "Tantalus on the Road to Asymptopia." Jounral of Economic Perspectives, 24(2), 31-46.

Levine, Ross; Renelt, David. 1992. "A Sensitivity Analysis of Cross-Country Growth Regressions." American Economic Review, 82(4), 942-63.

North, Douglas; John Wallis and Barry Weingast. 2009. Social Order: A Conceptual Framework for Interpreting Recorded Human History. Cambridge University Press.

Pritchett, Lant. 1997. "Divergence, Big Time." Journal of Economic Perspectives, 11(3), 3-17. 
. 2011. "How Good Are Good Transitions? Indonesia after Soeharto for Instance?" Employment, living standards and poverty in contemporary Indonesia.

. 2000. "Understanding Patterns of Economic Growth: Searching for Hills among Mountains,

Plateaus, and Plains." World Bank Economic Review, 14(2), 221-50.

Pritchett, Lant; Werker, Eric. 2012. "Developing the Guts of a Gut (Grand Unified Theory): Elite Commitment and Inclusive Growth." Effective States and Inclusive Development Research Centre (ESID) Working Paper No. 16/12.

Rodrik, Dani. 1999. "Where Did All the Growth Go? External Shocks, Social Conflict, and Growth Collapses." Journal of Economic Growth, 4(December), 358-412.

Rodrik, Dani; Subramanian, Arvind. 2004. "From "Hindu Growth" to Productivity Surge: The Mystery of the Indian Growth Transition." NBER Working Papers 10376 (March).

Rodrik, Dani; Wacziarg, Romain. 2005. "Do Democratic Transitions Produce Bad Economic Outcomes?" American Economic Review, 95(2), 50-55.

Sala-i-Martin, Xavier. 1997. "I Just Ran Four Million Regressions." NBER Working Paper No. 6252.

Shleifer, Andrei and Robert Vishny. 1993. "Corruption." Quarterly Journal of Economics, 108(3), 599614.

Silver, Nate. 2012. The Signal and the Noise: Why So Many Predications Fail--but Some Don't. New York NY: Penguin Press.

Taleb, Nassim Nicolas. 2007. The Black Swan: The Impact of the Highly Improbable. New York NY: Random House. 